\title{
GÁBOR LÁSZLÓ EMLÉKÜLÉS
}

Az MTA Épitészettudományi Bizottsága

2000. november 23-i

rendezvényének elöadásai 

A Magyar Tudományos Akadémia Építészettudományi Bizottsága 2000. november 23-án emlékülést rendezett névadója, Gábor László professzor, a Magyar Tudományos Akadémia rendes tagja születésének 90. évfordulójára, hogy bemutassa és méltassa e nagy előd életmüvét.

Gábor László, aki 1910-ben született és 1981-ben halt meg, a második világháborút követő évtizedek magyarországi építészképzésének meghatározó alakja volt, aki a Budapesti Múszaki Egyetem tanáraként elsősorban 1960 és 1979 között írt négykötetes Épületszerkezettan címú müve és egyetemi előadásai révén gyakorolt meghatározó hatást számos, egymást követő építészmérnök-generációra.

Az emlékülés - amelyen a megnyitó és az összefoglaló gondolatainak keretében 9 előadás és 4 hozzászólás hangzott el - elsősorban arra törekedett, hogy Gábor László oktatói és ezt megalapozó tudományos és tudományszervezői tevékenységét méltassa, de megkísérelte, hogy feltárja az életmünek azokat a rétegeit is, amelyek mindeddig kevéssé kerültek reflektorfénybe, vagy már kezdtek elhomályosodni a közemlékezésben.

Gábor László 1933-ban szerzett építészmérnöki oklevelet a Királyi József Müegyetemen, s ezt követően másfél évtizeden át tervező építészként müködött. Ez alatt villákat és bérházakat tervezett, majd a második világháború utáni három évben számos (részben vagy teljesen) lerombolt épület rekonstrukcióján dolgozott. Ezek közül a legismertebb a Margit-híd pesti hídfőjénél lévő, nagyon erősen sérült üzlet- és bérház átalakítása irodaházzá, amely először belügyminisztériumként, majd különböző pártfunkciókat szolgálóan múködve, a következő évtizedek egyik legjelentősebb szimbólumává vált, s ma is fontos (parlamenti) feladatot lát el.

Főosztályvezetői rangban rövid ideig az akkori Építésügyi Minisztériumban végzett államigazgatási tevékenység után tanszékvezető egyetemi tanárként 1949ben került át a Budapesti Műszaki Egyetem Épületszerkezettani Tanszékére, ahol haláláig dolgozott.

Ebben a munkakörben hozta létre a már említett négykötetes müvet, amely nem csupán átfogóan enciklopédikus igényü, hatalmas teljesítményként nevezetes, ha- 
nem azért is, mert abban és kapcsolódó kezdeményezéseiben nemzetközileg is jelentős erőfeszítéseket tett az épületszerkezettan épületfizikai, elsősorban hő- és hangtani, valamint hidromechanikai megalapozására. Ebben látszott meg legjobban személyiségének integratív ereje, amely sok tehetséges kutató bevonásában, kinevelésében és a kreatív egyéniségek szabad kibontakozását lehetővé tevő, de mégis szigorú követelményeket képviselő vezetésében nyilvánult meg.

Az akadémiai emlékülés előadásai mindezt részletesen illusztrálták, ugyanakkor rámutattak tevékenységének olyan mozzanataira is, amelyeknek ma is figyelemreméltó aktualitásuk van, s további folytatásra várnak. Ezek közül különös figyelmet érdemel a Zöld András munkásságára épített épületenergetikai kutatás, amely azóta a szoláris építészet épületszerkezeti felkarolásához vezetett (Széll Mária). További kiaknázásra várnak annak az akusztikai laboratóriumnak a lehetőségei is, amely a tanszék munkájához kapcsolódva megvalósult létesítmény, s Reis Frigyes akkreditációs erőfeszítéseit dicséri.

Az épületfizikai megalapozás átfogó feladatának teljesítése és az erre épülő korszerü szemlélet érvényesítése mellett Gábor László munkatársaival más fontos területeken is úttörő munkát végzett. Ilyen az informatika építészeti szerepének korai felismerése és ezzel kapcsolatos igen eredeti, nyelvtudományi analógiákat használó alapozó munkák kidolgozása. Ide sorolhatók a Christopher Alexander adaptálására támaszkodó lépések a gráfelmélet építészeti alkalmazására (Ottmár Béla) és a morfológiai alapelvek döntéselméleti érvényesítése az épületszerkezeti megoldások és választások optimálásának érdekében (Petró Bálint).

Igen jelentős Gábor László - Párkányi Mihály kutatásaira támaszkodó - részvétele a szerkezeti rendszerek elméletének fejlesztésében, amely a nem-tektonikus, felületelvü építési rendszerek alapelveinek kidolgozásában alkotott maradandót, s a „folding” építészeti mozgalmának elméletéhez is sokat adhat hozzá.

Az emlékülésen a Magyar Tudományos Akadémia két nemzetközileg elismert tagja is tartott - Gábor László által kifejtett állásfoglalások továbbgondolására ösztönző - előadást. Szabó János Gábor László építészeti filozófiáját elemezte, kiemelve az építészeti interdiszciplinaritás kettős (belső-külső) karakterére vonatkozó elgondolást. Finta József azzal foglalkozott, hogy a fiatal korában a Bauhaus-on orientálódó Gábor László, a posztmodern építészeti mozgalom fellépésére reagálva, miként tiltakozott az építészeti irracionalizmus ellen, s miként törekedett egy ezzel szembenéző építészeti etika megfogalmazására.

Gábor László egykori tanítványai és munkatársai Gábor László személyiségének életszerü bemutatását is fontosnak tartották, $\mathrm{s}$ az emlékülés ebben a tekintetben is emlékezetes marad. 


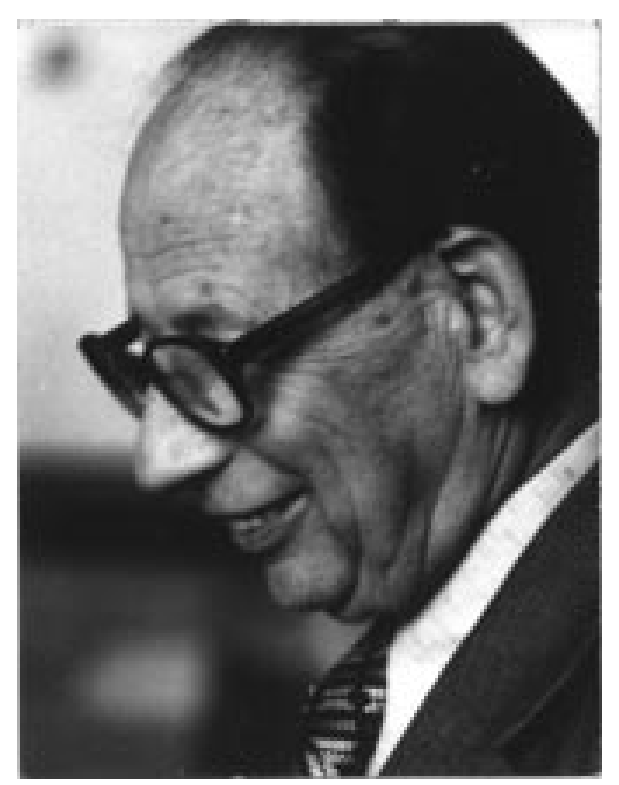

MEGNYITÓ

Gábor László a most búcsúzó évszázad magyar építészetének, építészettudományának és az épületszerkezettan egyetemi oktatásának hazánkban meghatározó, iskolateremtő személyisége volt. Kilencven éve született, s ezt az évfordulót ragadjuk meg arra, hogy megemlékezzünk életművéről és személyiségéről. Hasonló szándékból szokás szerint a nyolcvan- vagy a százéves évfordulót választják; mi azért választottuk a kilencvenest, mert valamikori fiatal munkatársai - jórészt neki köszönhető - pályájuknak már a csúcsára értek, s ezért a megemlékezésük különösen informatív lehet, a kevésbé fiatalok jó része pedig még elérhető, néhány év múlva viszont esetleg már nem lennének azok. Körünk sajnos már ma sem teljes; így nem lehet közöttünk Párkányi Mihály, akivel közösen Gábor László egyik legérdekesebb könyvét, Sámsondi Kiss Béla hallatlanul szellemes héjbeton-építésmódjának átfogó teóriává fejlesztését írta.

A mai emlékülést az Akadémia Építészettudományi Bizottsága rendezte, elsősorban Széll Máriának, a bizottság titkárának lankadatlan munkájával. Ez a bizottság Gábor Lászlónak köszönheti a létét, sőt még a nevét is. Korábban, a Széchy Károly által vezetett Építéstudományi Bizottság még magába foglalta az építési 
diszciplínák szinte teljes körét, a hídépítéstől kezdve, az épületszerkezettanon át, egészen a talajmechanikáig. 1964 és 1967 között, ennek a bizottságnak a titkáraként tanúja voltam számos vitának, amelyekben a különböző diszciplínák képviselői - közöttük pl. Csonka Pál és Gábor László - a tudományosság kritériumainak közös megállapítására, vagy az esetleg feloldhatatlan különbségeknek legalább a korrekt regisztrálására törekedtek. Azt hiszem, ezek a viták nagyban hozzájárultak ahhoz, hogy Gábor László törekvéseinek középpontjába állította az épületszerkezettan természettudományos - elsősorban a hőtant, a hangtant és a kapillárisok hidromechanikáját igénybevevő - megalapozásának programját. Emlékülésünk egyik feladata annak a felmérése, hogy ennek a programnak a megvalósításában meddig jutottunk, s hogy mik lennének a következő legfontosabb megteendő lépések. Erre azért is szükség van, mert az építéshez-építészethez tartozó diszciplínák és a művelésükre szakosodott akadémiai bizottságok között létrejött módszertani vetélkedés-háborúskodás ma is tart, s ennek alakulásától bizottságunk, az Építészettudományi Bizottság jövője is függ.

Kunszt György

\section{GÁBOR LÁSZLÓ ÉLETRAJZÁHOZ}

Születési helye, ideje: Debrecen, 1910. november 22.

Elhalálozásának ideje:1981. október 28.

Középiskolai tanulmányok: Debreceni Állami Főreáliskola

Egyetemi tanulmányok: Kir. József Mủegyetem Építészeti Osztály, 1929/30 1932/33. tanév

Végzettsége: okleveles építészmérnök

Oklevelének száma, kelte: 11754; 1933. május 2.

Munkahelyei, beosztásai:

Tervezőként dolgozik

Ligeti Aurél (1932-35),

Platschek Imre (1936-39),

Dereskei Fodor Lajos (1939-41),

Mátrai Gottwald Gyula (1941-44) építészek irodáiban.

Önálló építész tervező, 1946-48 
Hazai Mély- és Magasépítő Rt. 1948. április - május, vállalatvezető

Magasépítőipari Igazgatóság, 1948. május - július, igazgatóhelyettes

Építésügyi Minisztérium, 1948. július - 1949. október, főosztályvezető

Budapesti Müszaki Egyetem, Épületszerkezeti Tanszék, 1949. október - 1952. augusztus, tanszékvezető egyetemi tanár

Építőipari Műszaki Egyetem, Épületszerkezeti Tanszék, 1952. szeptember-1955. augusztus, tanszékvezető egyetemi tanár

Építőipari és Közlekedési Műszaki Egyetem, Épületszerkezeti Tanszék, 1955. szeptember - 1967. augusztus, tanszékvezető egyetemi tanár

Budapesti Müszaki Egyetem, Épületszerkezeti Tanszék, 1967. szeptember-1981. június 30. tanszékvezető, egyetemi tanár

\section{Tudományos fokozatai:}

a műszaki tudomány doktora, 1958. szeptember 22.

MTA levelező tag, 1973. május 30-tól

MTA rendes tag, 1979-töl 


\title{
GÁBOR LÁSZLÓ \\ ÉPÍTÉS-ÉPÍTÉSZET FILOZÓFIÁJA ÉS REGULÁJA
}

\author{
SZABÓ JÁNOS
}

akadémikus

Személyes kapcsolatom Gábor Lászlóval 53 évvel ezelőtt kezdődött, és ebben a véletlen is szerepet játszott. 1943-ban megszereztem a mérnöki oklevelet. 1943 októberében behívtak katonai szolgálatra. 1947 őszén érkeztem haza szovjet hadifogságból. Állásom nem volt, több helyen próbálkoztam, míg végül azt ajánlották nekem, keressem fel egy szervező-fejlesztő-tervező vállalatnál Bartos Istvánt (akivel akkor találkoztam először), mert neki szüksége van szerkezet-tervező mérnökre. Októberben már nála dolgoztam. Akkoriban indult a teljesen romos Palatínus bérház-tömb Belügyminisztérium részére történő átépítésének előkészítő munkája. Nem sokkal ezután kerültem szoros kapcsolatba a tervezés szervezőivel és végrehajtóival, név szerint: ifj. Benkhard Ágoston, Gábor László, Gádoros Lajos, Preisich Gábor, Rudnai Gyula építészekkel és munkatársaikkal. Mi, Bartos István és csapata (kezdetben Rózsa Mihály és jómagam) végeztük a szerkezettervezést. Bátran mondhatom, hogy ez az ötven évvel ezelőtt újjászületett épület, figyelembe véve a többször változó felhasználók igényeit is, ma is megfelel a követelményeknek. Jelenleg, úgy tudom, országgyúlési képviselői irodaház.

A BM-nek szánt épület elkészülte után ritkábban találkoztam Gábor Lászlóval, de változatlan tisztelettel fogadtam az építészet elméleti és gyakorlati összefüggéseit illető felfogását, filozófiáját. A nálam tíz évvel idősebb Gábor László megalapozott szemléletét, nyíltan vállalt felfogását ma is helytállónak tartom. Ezért mertem vállalkozni arra, hogy filozófiájáról beszéljek, mert annak tartalmát nem csak elfogadtam, hanem az övétől eltérő pályafutásom során is irányelvnek tekintettem. Természetesen senkire sem kötelező felfogás ez: bárki fogalmazhat másképpen, egy másfajta filozófia is vezethet nemes vagy annak vélt célok felé.

Semmi okunk sincs arra, hogy szemlesütve, szégyenkezve jelentsük ki, hogy az építés az értelmes emberi tevékenység legősibb és ma is változatlanul egyik legfontosabb eleme, egészséges létének nélkülözhetetlen eszköze. Gábor László definíciója szerint a legegyszerübb és a legfejlettebb formájában egyaránt művészetből, tudományból és technikából ötvöződő kerek egész. E kijelentés lényege nem 
attól függ, hogy a három összetevő milyen színvonalú (mennyire emberi, vagy mennyire tudálékos). Mikor ismételten élvezettel lapozgatom Finta József Rajzoskönyvét, akkor a legegyszerübb bikali csűrnél is érzem az építő ember szépre törekvését, a szakmai tudást és a tudni hogyant, azaz a know-how-t. Itt meg kell jegyeznem, hogy az építésre vonatkozó hármas (művészet, tudomány, technika) követelmény kimondása csak akkor elegendő, ha a gazdaság egészében az optimális megoldás kiválasztása egy korrekt ár- és értékrendre épül. Voluntarista, illetve protekcionista árrendszerben a vélt optimumhoz képest állandósul az erőforráspocsékolás. Ezt a hetvenes években megvalósult müszaki fejlesztés sajnálatos csődje is igazolja.

Gábor László korán felismerte, hogy az építészetnek különösen nagy a társadalmi hatása és jelentősége, tudományterülete roppant dinamikusan fejlődik, interdiszciplináris jellege a múszaki tudományok között a legösszetettebb. Ez késztette saját filozófiája egyértelmủ megfogalmazására. Változatlanul érvényesnek tekintette az építészettudománynak a húszas-harmincas években megfogalmazott tételét: az építészet és a városépítészet egyetemes jelenségei mögött társadalmi erők, ideológiai szemléletek, sőt politikai feszültségek is meghúzódnak, az építészettel szemben támasztott követelmények jellegzetesen társadalmi szinten fogalmazódnak meg, következésképpen azok kielégítése is csak társadalmi téren oldható meg.

A problémák alapvetően társadalmi (politikai) jellegéből levonható következtetéseket Gábor László a következő négy pontba csoportosította:

1. Az építészet kérdéseire adott válaszok tudományos szempontból csak akkor hitelt érdemlöek, ha közvetlenül, vagy közvetve a társadalmi kérdéseket is megválaszolják.

2. A válaszoknak meg kell maradniuk a racionalitás világában.

3. Az ipari szintre emelt épitészeti, város-épitészeti megoldások - müszaki szempontból is - csak akkor tekinthetök elfogadhatóknak, ha azok közvetlenül vagy áttételesen a politikai, társadalmi és szociológiai, funkcionális és pszichológiai, esztétikai és szemiotikai (jelkép-rendszeri) követelményeket egyidejüleg kielégítik, és ha e megoldások a társadalmi fejlödés, átalakulás megértését, a változások okainak és folyamatainak felismerését tükrözik, és a történelem, a társadalom által feltett ésszerü kérdések ésszerü megválaszolását is lehetövé teszik.

4. Nem utolsó sorban alapos vizsgálatot és bölcs döntést igényel az épitészettel kapcsolatos új elméletek felbukkanása és terjedése, melyekhez új célokat, új alkotási szemléleteket és módszereket hirdetnek meg, új tudományos eredmények keletkeznek, új feltételek, követelmények jelennek meg, és hogy mindezek eredményeként sok az eszmei zavar, sok az elvi félreértés, a gyakorlati tévedés, az értékelési bizonytalanság. 
Gábor László nem tudott és nem akart azonosulni a XX. században jelentkező, gátlástalan, nem konstruktív kritizálással, a legkiválóbb építészi alkotások és ezek alkotói pocskondiázásával (köztük szerepelt Frank Lloyd Wright, Mies van der Rohe, Walter Gropius, Le Corbusier is). Tudomásul kell venni, hogy az építészet történetének évszázadai alatt természetes törekvés volt a stílus, tartalom, forma stb. állandó megújítása, s bár lehet, hogy az utódok akkor is ócsárolták elődjeik múveit, de számunkra kötelesség a megmaradt, vagy ásatásokkal feltárt hagyaték megőrzése.

Sok, vele egyező felfogású építészhez hasonlóan Gábor László vallotta, hogy az új elméletekkel felvázolt világkép feltünöen nem teljes, mondhatni hamis, hiszen a teljes problémakör nem szükithetö le a leggazdagabb országok világára és nézöpontjára; ezért is szilárdan hiszi, hogy a „modern épitészet” haláláról értelmetlenség beszélni, söt nagyon is messze van lehetöségeinek kimeritésétöl, meg se közelitette teljesitöképessége határait; meggyözödése, hogy az igazi épités- épitészettudomány ezzel az épitészettel lépett be a jóformán csak a tapasztalat próbájában bizó, és fóként arra támaszkodó épiteni tudás helyébe, ennek keretében zárkózikfel a kor tudományos és technikai színvonalához; változatlanul úgy tartja, hogy ez az az épitészet, amelyet problémamegközelitési módjának elfogulatlansága, emberközpontúsága, tudomány iránti elkötelezettsége, társadalmi érzékenysége egyaránt alkalmassá tesz a városléptékü és tömeges feladatok (jelenös részének) ellátására, és a kort jellemzö, jelképezö csúcsteljesitmények elérésére is, tehát a ragyogó müvészeti, a nagyszerü mérnöki, a roppant technikai és az óriási méretü és felelősségü alkotások, teljesitmények létrehozására.

Gábor László megállapítja, hogy az épitészet szemléleti és törekvés-spektruma a fejlödési folyamatban nagyon kiszélesedik, és az épités-épitészettudomány problémakörében a tényezök száma folyamatosan nö, rendkivül összetetté és különösen komplexszé válik. A problémakör sajátszerüségének vizsgálatakor célszerü a tényezök közül a legfontosabbak kiválasztása.

Az épités- épitészettudomány területén a sok tényezö közül három semmi esetre se mellözhetö, ezek: a társadalom, mert ez az egész épitési tevékenység feladatkörének meghatározója, szinhelye és kerete; a technika, hiszen ez az épitési-tevékenység, a megvalósitás eszköze; a tudomány, mert ez az általános fejlödés eredményeként közvetlenül termelöerövé válik.

E három tényezöböl kiindulva a sajátszerüség vizsgálatát azokra a területekre célszerü irányitani, ahol az emlitett tényezök a legjellegzetesebben érvényesülnek. Napjaink épitészetében két ilyen élesen elkülönülö, akár ellentettnek tekinthetö terület van.

Az egyik a hétköznapok világa, a tömeges épités területe. Ez azért kerül az épitészet egyik pólusára, mert az a mindenki által nagyon is jól ismert követelmény, 
hogy minél, jobban, szebben, változatosabban, változtathatóbban stb. kell épiteni, és az a társadalmi szintü kikötés, hogy mindezt adott helyen és idöben, mindig szigorú müszaki és szükös gazdasági feltételek mellett kell teljesiteni. Ez nehezen feloldható ellentmondást teremt az igények és kielégitésük lehetösége között, és végső soron oda vezet, hogy ezt a roppant méretü, társadalmi fontosságú és politikai jelentöségü feladatot az ipar teljes felkészültsége mellett sem tudja minden vonatkozásban, egymagában megoldani.

A másik a csodák világa, az épitészeti csúcsteljesitmények területe. Ez azért kerül a másik pólusra, mert itt mindig valamilyen kiemelkedö jelentöségü egyedi feladat megoldásáról van szó, mert a cél az adott helyen, időben és adott körülmények között a megvalósitható legtökéletesebb keresése, pl. a legmagasabb, a legkülönlegesebb, a leglátványosabb, a legjobban felszerelt, a legnagyobb komfortot nyújtó stb. épület létrehozása, mert ehhez mind a társadalmi fedezetet, mind a müszaki feltételeket ideális szinten biztositják, és végrehajtásához az ipar a megvalósitás minden eszközével rendelkezik.

E két polárisan ellentett világnak jellegzetesen közös ismérve az, hogy bennük az épités- épitészettudomány három fö összetevője: a müvészet, a tudomány és a technika társadalmi szinten elvileg maximális igénnyel lép fel, jellegzetesen megkülönböztetö vonása pedig az, hogy e feltétel a hétköznapok világában eddig nem bizonyult teljesithetönek.

Gábor László szerint e feltünö hiányosság - amelyben, ha jól meggondoljuk, korunk épitőiparának és épitéstudományának egyik alapvetö ellentmondása fogalmazódik meg - néhány nagyon is jól belátható külső és nehezebben elemezhetö belső okra vezethetö vissza. ${ }^{*}$ Itt sajnos a hétköznapokra vonatkozó elemzésre nem csak idő hiányában lehetetlen kitérnem, hanem azért is, mert ez Gábor László filozófiai fejtegetésének általam is teljesen elfogadott tartományán kívül esik, és csak a jelenleg uralkodó voluntarista ár- és értékrend - egy remélt jövőbeli - drasztikus felszámolásával lesz kezelhető (félreértések elkerülése végett tudomásul kell venni, hogy e kényes kérdés megoldásához a rendszerváltás előtti és utáni kormányok egyike se mert hozzányúlni).

Az eddig elmondottakhoz képest lényegesen rövidebben (nem fontosságát lebecsülve) szeretném vázolni Gábor László reguláját, értve ez alatt a szabályozást, rendteremtést. Nos, az Épületszerkezettan címú, négykötetes, több kiadásban megjelent mű (mondhatnám „épszerk-biblia”) minden részletre kiterjedő alaposságát és grafikai precizitásának szépségét csodálja még az is, aki nap-nap után kezébe

* Az előadás kéziratában szereplő kurzív szedésủ szövegrészeket, nem lényeges kisebb változtatásokkal és csoportosítással Gábor László 1980. évi MTA székfoglalójának kéziratából állítottam össze. 
veszi. E reguláról a jelen meghívó belső oldalán elhelyezett harmadik mondat elmondja a lényeget: „Gábor professzor az épületszerkezettant objektív kritériumokra alapozott tudománnyá fejlesztette, de mindig az épület- és szerkezettervezés eszközeként kezelte, s nem, mint technikai, technológiai öncélt.”

* Az Emlékülésen szerettem volna elmondani - mint Gábor László kiváló építészi kvalitására jellemzőt - az annak idején BM célra tervezett épületre vonatkozó egyik tervezési-építési emlékemet, de nem akartam ezzel a beszédidő-fegyelmet megsérteni. Ezért az alábbiakban közlöm:

Az épület Dunára néző, tervezett főbejárata az eredeti épület egyik igénytelen belső udvarára nyílott. Gábor László ezt igényes előcsarnokká kívánta alakítani, úgy hogy a földszint és az első emelet falait kibontva, azokat kör keresztmetszetű oszlopokkal váltja ki, az első emeletet az előcsarnokra néző galériává alakítja, és a felette lévő födém vonalában helyezi el az előcsarnokot lefedő üvegezett acél tetőszerkezetet. Természetesen az oszlopokat az előcsarnokhoz illő kőburkolattal kívánta ellátni. Vázlatai nekem is nagyon tetszettek, és lelkesen elkészítettem a kiváltás vasbeton szerkezeti és munkaszervezési terveit. (Mondanom se kell, hogy az általa elképzelt oszlopoknak hat emelet tömör falainak terhét kellett viselniük.) Mikor megmutattam neki a tervet, elszörnyedt és így szólt: Jancsikám, én nem dór, hanem szép karcsú oszlopokra gondoltam, találj ki valami elfogadható megoldást! Természetesen teljesítettem kívánságát: rejtett acélszerkezetekkel terveztem az oszlopokat és a galériakiváltásokat. Ezzel már Gábor László is meg volt elégedve. Az eredménynek én is örültem, mert mikor az előcsarnok elkészült (a padló és egyéb burkolatokkal együtt) akkor igazolódott Gábor László felfogása, miszerint „,a részletekben is igényesnek kell lenni!’ 


\title{
GÁBOR LÁSZLÓ ISKOLATEREMTŐ MUNKÁSSÁGA
}

\author{
PETRÓ BÁLINT \\ egyetemi tanár
}

Az iskolateremtő - alkotásai, munkája során - új gondolkodási modellt alakít ki, amely modell a későbbiekben általánosan elterjed és használhatóvá válik a szakma meghatározott területein.

Ebből következik, hogy az képes ,iskolát teremteni”, akinek potenciálisan van iskolája; aki alapvetően új tartalommal, gondolatokkal tudja megtölteni az iskola tananyagát; és aki képes e gondolatok átadására, egy újszerű gondolkodásmód kialakítására, „hallgatói”, követői körében.

Ha ezen meghatározás igaz - márpedig véleményem szerint egyértelmúen az -, úgy vizsgáljuk meg, hogyan érvényesül e tézis szeretve tisztelt professzorunk, Gábor László tanár úr esetében, akinek iskolateremtő munkásságát két irányban szeretném bemutatni: egyrészt saját pályafutásom tapasztalatai alapján, ugyanis Gábor László több mint 20 éven keresztül közvetlen fönököm, tanítómesterem volt, másrészt elvi alapokon megközelítve Gábor László iskolateremtő tevékenységét, konkrét példákon keresztül. Úgy vélem, hogy e két kiindulási pont mondanivalómat hitelessé és egyértelmúvé teszi.

Személyes tapasztalataim az iskoláról: Munkahelyi főnökeim szempontjából szerencsés embernek mondhatom magam. Két jelentős munkahelyem volt ez ideig - eltekintve a néhány hónapos technikumi és egyetemi, munkahelyi, illetve külföldi oktatói gyakorlatoktól - az IPARTERV 6-os irodája és a BME Épületszerkezettani Tanszéke, amelynek vezető professzora már az 1960-as évek elején is Gábor László egyetemi tanár volt. A végzés utáni három éves IPARTERV-i tervezőirodai múködésem során Mátrai Gottwald Gyula (kétszeres Kossuth-díjas) irodavezető volt a főnököm, aki korábban, a II. világháború előtt, a BE-GÁ-GO (Benkhard-Gábor-Gottwald) munkaközösségben együtt dolgozott későbbi főnökömmel, Gábor tanár úrral. Az IPARTERV jó „,cselédkönyvezés” volt mindenki számára, így az én számomra is, és innen kerültem vissza az Egyetemre, mégpedig Gábor tanár úr tanszékére, iskolájába. 
Az iskola és az iskola vezetője a szakma széles körú ismeretét követelte meg tanítványaitól mind a gyakorlat, mind pedig az elmélet vonatkozásában. Ennek értelmében, az első félévben az egyes szakterületek néhány ismereti hiányosságát kellett pótolnom, elsősorban a szakipar és a kutatómunka területén. Így egy-egy hónapot kellett eltöltenem a Ferencvárosi Asztalos Üzemben, az Albertfalvai Kőfaragónál, az Országos Szakipari Vállalatnál és az Építéstudományi Intézetben, ahol is lehetőségem volt a fent említett hiányosságok pótlására, illetve a szakma e területeinek közelebbi megismerésére. Az elkövetkező időben Gábor László megtanított a könyvtár és a folyóiratok használatára (Lévai Andor professzor úr - Bandi bácsi - irányításával), majd beavatott a könyvírás rejtelmeibe, vezetése alatt, mint munkatárs müködtem közre az Épületszerkezettan II-IV. kötet készítésében. Ilyen egyszerü és hasznos volt Gábor tanár úr iskolájába járni. A fentiekből egyértelmủen kitünik, hogy az iskola vezetője folyamatosan törődött beosztottjaival, azok fejlődésével és szakmai előmenetelével. De ugyanakkor megkövetelte az önállóságot is. Elvárta a publikációs tevékenységet, félévenként egy-egy cikk megjelentetését a szaklapokban. Minden megjelenő cikket előbb átolvasott, mind szakmailag, mind pedig stilisztikai szempontból lektorált. Mondása: ,amely írás stilisztikai szempontból hibás, az már szakmai szempontból sem lehet jó" - Ö ugyanis jelentôs általános irodalmi múveltséggel is rendelkező építész professzor volt.

Az önállóságra nevelés másik fontos tényezője volt, hogy hagyta önállóan dolgozni munkatársait. Hasonlóan Mátrai Gottwald Gyulához, nem „fogta” tanítványai kezét, miközben a vonalakat húzták, Öt csupán a végeredmény érdekelte, amit viszont éles kritikával illetett. A „tézis” volt a lényeg, és ha ez megállta a helyét az „ördög ügyvédjével” szemben, akkor „zöld utat” kapott a tanítvány alkotása, illetve munkája.

Az irott anyag, szakmai szöveg (szakcikkek, szakkönyvek) és az elöadások stílus-viszonyairól: Mint az köztudott, Gábor tanár úr írásai tömörek, jelentős odafigyeléssel, koncentrálással olvashatók, értelmezhetők, bár stilisztikai szempontból kifogástalanok, míg előadásai könnyedek, szellemesen sziporkázóak, érdekesek, könnyen érthető́k voltak. Mikor ennek okát kérdeztem, válasza egyértelmú volt: a könyvben, ha valamit nem ért az olvasó (ugyanis a „,vevőberendezés” az egyének vonatkozásában különbözö) visszalapozhat, sőt többször is elolvashatja azt, míg az előadás csupán egyszer hangzik el és az mindenki számára azonnal világossá, érthetővé kell, hogy váljék. Úgy vélem ez is egy alapigazság, amely minden íróelőadó kolléga számára megfontolandó, megszívlelendő.

Az iskola új tartalmi eredményeiröl: Véleményem szerint a legnagyobb eredménye Gábor professzor úr iskolájának - ami nem kézzel fogható és közvetlen nem megjeleníthető - ,a módszer, a törekvés a tanítványok gondolkodásmódjának 
megváltoztatására". Úgy vélem, ez a legnehezebb feladat, ebbe beavatkozni, ezt megváltoztatni. Hogyan nyilvánult meg ez konkrétan: szisztematikus gondolkodásmódra nevelni, az ok-okozati összefüggéseket feltárni, a feladatmegoldásban az egészből kell kiindulni, és fokozatosan haladni a részletek felé, és folyamatosan visszacsatolni a problémamegoldás során (azaz a részletek a későbbiekben befolyásolhatják a korábban meghozott döntéseket). Lehet, hogy ez triviálisnak tünik, de későbbi tapasztalataim alapján állítom, hogy a gondolkodási módot befolyásoló alaptörvényszerüségek döntő fontosságúvá váltak további munkáim során, ugyanis az alkotás eredményét, annak nívóját a „módszer” jelentős mértékben befolyásolja.

Könyveinek színvonalát is e szisztematikus gondolkodásmód fogja egységes keretbe, és ez teszi napjainkban is használható, széles körben elterjedt és alkalmazott tankönyvekké, amelyeken építészmérnökök generációi nőttek fel.

Újat alkotott és új modellt vezetett be az épületszerkezettan és a fizika tudományterületeinek összekapcsolásával, az épületszerkezetek tervezését tudományos alapokra helyezte, külön kiemelve a hő-, a pára- és az épületakusztikai folyamatok figyelembevételének fontosságát és szükségszerüségét az épületszerkezetek tervezése során.

Ily módon vezetésével az iskola megoldotta a külső és belső térelhatároló szerkezetek (falak, tetők, közbenső födémek, nyílászárók stb.) épületfizikai elemzését, követelményrendszerét az épületfunkció függvényében, valamint javaslatok készültek a közel optimális szerkezeti megoldásokra.

Összességében kidolgozásra került - a korábban csupán empirikus alapokon létrejött és évtizedeken keresztül alkalmazott épületszerkezetekkel szemben - az új anyagok felhasználásával létesítendő új szerkezetek tudatos szerkezettervezési folyamata, valamint sor került ezek bevezetésére az építőipar tervezői, kivitelezői gyakorlatában.

Összefoglalás: E tanulmány, előadás megírásával és elmondásával szerettem volna - a kötelező tiszteletadáson túlmenően - azt a célt elérni, hogy Gábor László professzor úr iskolateremtő munkássága, annak jellemző motívumai - amelyek véleményem szerint ennyi év távlatából is megállják helyüket - ne vesszenek el az utódok számára. Ezen iskola - több évtizedes múködése során kialakult - eredményeinek számos elemét alkalmazzák vezető professzoraink napi munkájuk során ma is, a színvonalas oktatás-kutatás, valamint az utódok kinevelése területén.

Napjainkban is büszke vagyok arra, hogy Gábor tanár úr iskolájának tagja lehettem, és most, posztumusz is megköszönöm azt a sok fáradozást és gondoskodást, amelyet szakmai fejlődésem, előmenetelem érdekében kifejtett. 


\title{
GÁBOR PROFESSZOR, A KUTATÓ
}

\author{
ZÖLD ANDRÁS \\ egyetemi tanár
}

Manapság, amikor a tudományos teljesítmény mérésének is kialakult a tudománya és technológiája, egy tudományos életmű, vagy egy adott időszakban elért eredmények értékelését többnyire azzal kezdik, egy-egy pályázat súlyát azzal adják meg, hogy az illető publikált / referált, nem referált magyar / idegen nyelvü cikket, belföldön / külföldön megjelenő folyóiratban, tartott ennyi / annyi belföldi / külföldi konferencia-előadást, abból mennyi volt az invited / plenary / keynote / referred paper, megjelent-e proceedingsben, mennyi az impact faktorok kumulált értéke, milyen a szerző citátum indexe. Nem vitás, egyes szakterületeken ez múködik, Magyarországon is, vagy ha korábban nem is múködött, most már kialakultak / kialakulóban vannak a megfelelő publikációs fórumok. Egyes területeken azonban még nincsenek ilyenek, vagy ha ma már vannak is, korábban nem voltak.

Természetesen nem mellékes az a kor, amelyben valaki dolgozott. Ma egy végzős ötödéves hallgató szélesebb nemzetközi kapcsolatokkal bír és többet utazott, mint emberöltővel ezelőtt a befutottnak mondott oktatók többsége. Ugye néhányan emlékszünk még a titkosítási eljárásokra: a nyilatkozatokra és igazolásokra, miszerint cikkünk állami és szolgálati titkot nem tartalmaz, ennek egyetemi, minisztériumi ellenőrzésére, a lepecsételt dupla borítékra, amelynek tartalma a határon vámvizsgálat tárgya volt - persze az, hogy mi volt a kiutazó fejében, az nem volt kérdés. De emlékezhetünk néhányan az 1986-os PLEA konferenciára, az egyik itthoni nagy nemzetközi rendezvényre, amelynek kiadványát / proceedingsét a külhoni résztvevők elvileg csak a vámhivatal engedélyével vihették magukkal.

Ha a tudomány mérésének mai technológiáját alkalmaznánk, lehet, hogy Gábor László életmúve nem is kerülne toplistára. Hogyan lehet mégis, hogy a szakmai közvélemény az elsők között tartja számon? Talán azért, mert amit Ö írt, az nem csak egy szúkebb tudós társaságnak szánt eszmefuttatás volt, amire replikákat lehet írni és bőven lehet egymástól citálni. Gábor professzor egy jóval szélesebb körhöz is, vagy főleg ahhoz szólt, ma úgy mondanánk, célcsoportját, target groupját a 
szakma minden - az újra nyitott - építésze, mérnöke alkotta, az Ő szakmai tudásukat gyarapította.

Mondanivalóját olyan szabatos, tömör formában tudta előadni, amely párját ritkította. Ha szabad e komoly fórumon ilyen ünnepi alkalommal humorizálni - Ö ehhez bizonyára hozzájárulna - mint szerzőpárja az Energiagazdálkodás az épitészetben c. könyv esetében ugyancsak átéltem e (pár)ritkítás élményét, amikor kézirataimat harmadszor és negyedszer is együtt átrágva, azok eredeti terjedelmük felére, harmadára zsugorodtak anélkül, hogy tartalmuk csorbát szenvedett volna. Igencsak tanulságos volt.

Lehet, hogy e sajátos szabad-versek néha nem könnyủ olvasmányok, de egy blokksémához, egy matematikai algoritmushoz hasonló szabatosságuk, szigorú szerkezetük az okok-okozatok-összefüggések ritka világos rendszerének feltárásához, megértéséhez kiváló alapokat biztosítottak.

Miért, miben volt tehát Ő valóban nagy? Számos tudós egy-egy szűkebb részterület mélyebb ismeretével vált ki a kutatók seregéből. Azt hiszem, nem túlzás azt állítani, hogy amiről Gábor professzor publikált, előadott, az mind azt bizonyította, hogy a szóban forgó részterületet mélyebben ismeri. Csakhogy Ő az épületszerkezettan szinte minden részterületéről publikált - vagyis mindet mélyebben ismerte, ebben is különbözött a szokványostól. De nemcsak az egyes részeket látta át kitünően, hanem azok összefüggéseit, és ezáltal az egészet is - sőt az építéstudomány és az általa külsőnek nevezett interdiszciplináris területek kölcsönhatásait is - egészen merész és távoli, nem utolsósorban sikeres kirándulásokat téve olyan területeken is, amelyek az informatikával, az energiagazdálkodással függenek össze. Ez ma már természetesebben hangzik, csakhogy ne feledjük, ezekre a „túrákra” egy negyedszázaddal ezelött került sor.

Gábor professzor egy-egy problémát mindig összefüggéseivel együtt vizsgált. Azt vallotta: ,Az épitészet egyetemes jelenségei mögött társadalmi erők, ideológiai szemléletek, sőt politikai feszültségek is meghúzódnak,...az épitészettel szemben ma támasztott követelmények...jellegzetesen társadalmi szinten fogalmazódnak meg, következésképpen azok kielégitése is csak társadalmi téren oldható meg." Éppen ezért azt állította, hogy „,... az épitészet kérdéseire adott válaszok-legyen azok jellege bár technikai / ipari vagy müvészeti / ideológiai - tudományos szempontból csak akkor hitelt érdemlöek, ha közvetlenül vagy közvetve a társadalmi kérdéseket is megválaszolják. " Hogy ezek a gondolatok mennyire érvényesek ma is, arra talán elegendő az aktuális problémák közül a fenntartható fejlödés vagy a lakásépítés kérdéseit említeni.

Múködésének időszakában az egyik legfontosabb téma a tömeges építés volt. Elemezte ennek ellentmondásait és hiányosságait, amelyek külső okait abban látta, hogy ,.... a termék tömeges, a megvalósitás szétszórt, a müvészi érvényesitésének lehetösége potenciálisan a legkisebb, az értékelés alapja a hasznosság. " Úgy vél- 
te, hogy „,... ha a tömegességet a müvészi igényével kell társitani (és írásaiból egyértelmúen kitünik: remélte, hogy ez bekövetkezik) akkor olyan ipar kell, amely az esztétikai igények kielégitésére is alkalmas ... az iparositott épitészetben (sic! nem építés - Ó, aki minden kötőszót is alaposan megfontolt, bizonyára nem véletlenül írta így), a gyártó gépek átállithatósága szükséges."

Az általánosabb megállapításokon túl mélyebb elemzéseket is végzett. Elegendő a Dr. Párkányi Mihállyal közösen írott könyveire utalni, amelyek a nem tektonikus szerkezetekről, valamint az informatika szerepéről szólnak, amelyek a variálhatóság, a vaktervezés avagy - a későbbi szóhasználattal - az absztrakt építészet kérdéseit taglalják. A kódolás / dekódolás kézi elvégzése lehetőségeinek bemutatása egy új információátviteli technikát ígért - amelyhez annak idején, még nem volt nálunk hozzáférhető a megfelelő hardware -, de akkor még egy ODRA típusú gépre járt az Építő- és az Építészmérnöki Kar, amelynek éjjeliszekrény méretű dob-tárolója egy floppy-nyi adatot sem tudott befogadni. Elképzelhetô - talán - mi lett volna a munka eredménye a mai technikai lehetőségek mellett.

Miközben szükebb körben, élőszóban szakterületét szerényen és nem csekély öniróniával „csak” egy nagy enciklopédiának nevezte, komoly formában annak sajátszerüségeit két kategóriába csoportosítva a következőkben foglalta össze.

Megfogalmazása szerint, a ,sajátszerüség első jellemvonás-csoportjába” sorolta azokat a tényeket, amelyek az építészettudomány és más tudományterületek összevetéséből következtek. Megállapította többek között azt, hogy „az épitésépitészettudomány - a többi müszaki tudománynál sokkal inkább elválaszthatatlanul kapcsolódik a müvészihez, az egész humán szférához. E tekintetben az interdiszciplinaritás sajátos kettös esete forog fenn: a humán szféra benne foglaltatik az épitészettudományban, de körül is veszi azt.” Kiemelte: „,.. a végtermék: az épület és az ezekböl kialakuló együttesek és az együttesekböl szervezödő város temérdek szállal és közvetlenül kapcsolódik a társadalomhoz, és azon belül az egyes emberekhez is, az utólagos átalakithatóság a társadalmilag szükséges és emberileg is indokolt későbbi igazodás lehetőségét célozza."

A , sajátszerüség második jellemvonáscsoportjában” azt emelte ki, hogy

- ,... az épiteni tudás minden más müszaki tudománytól eltérően nagyon is sok és jellegzetesen különnemü technikák, tudások összessége, ezért sem a benne rejlö egyes (belsö) tudományok / mesterségek, sem a (külsö) természet- és müszaki tudományok szemlélete, szempontjai, módszerei nem küszöbölhetök ki,

- ... az interdiszciplinaritás belülröl is, kivülröl is hat...,

- ... a belsö tudományok / mesterségek egymásra is hatnak, együttesen csak arányosan fejlödhetnek,

- ... a külsö tudományok hatására az épitéstudomány csak integrált egészként válaszolhat." 
Nyilván ez a szemlélet ad magyarázatot arra, hogy miért is dolgozott olyan széles skálán, miért volt annyira nyitott az újra, az épületszerkezettannal összefüggő, de annak hagyományos részét nem képező, a határterületekhez, a „külső” interdiszciplináris tudományokhoz tartozó témák irányában. Ez utóbbiak lényegét is igen hamar átlátta, és könnyen tudott együttmúködni e szakterületek képviselőivel. Személyes tapasztalat mondatja ezt velem: abban a szerencsében volt részem, hogy Vele közösen könyvet írhattam - hogy én sokat tanultam ebből, arra is már utaltam korábban. De hogy Ö milyen hamar, mennyire átlátta az én szakterületem lényegét és annak összefüggéseit az általa múvelt területtel, azt nemcsak a közös munka során volt alkalmam megtapasztalni, hanem akkor is, amikor utolsó disszertációmon dolgoztam. Mint főnököm, összeférhetetlenség okán nem volt jelölhető hivatalos bírálói vagy bizottsági szerepre. De mint „szívességből közremüködő” „ördög ügyvédjétől” olyan bírálatokat, olyan kérdéseket kaptam Tőle első kéziratomra, amelyek mélységükben, következetességükben önmagukban meghaladták a három hivatalos bírálótól kapott észrevételek összességét.

Egy tudós nemcsak önmagában, hanem tanítványaiban, szakmai utódaiban is él, fennmaradásának, életmúve folytatásának ez az egyik legfontosabb formája. Hogy hány építészmérnöknek tanította meg a szakma alapjait, hánynak a szemléletét formálta úgy, hogy azok később önállóan, alkotó módon legyenek képesek tudásukat alkalmazni, továbbfejleszteni, hogy tankönyveit hányan, hány országban használják még ma is alapműként, arról Gábor professzor oktatói munkásságának méltatása során esett és esik szó. Hogy alapmúvének, a négykötetes Épületszerkezettan tankönyvnek megírása során milyen hatékonyan tudott együttmüködni belső és külső munkatársaival, hogyan tudta integrálni, egybeötvözni azok ismereteinek, grafikai készségeinek legjavát, azt irodalmi munkásságának értékelésénél hallottuk. Itt most csak a kutatói utánpótlás kérdését érinteném. Nyilvánvaló, hogy ehhez alkalmas kollegák is kellettek, de az irányításon is múlott, hogy Gábor professzor vezetői múködése alatt tanszékén több mint fél tucat disszertáció született, az akkori struktúrának megfelelő doktori illetve kandidátusi szinteken, és e szám még nagyobb, ha tanszékének ,vonzáskörzetét” is beszámítanánk. Ma is nagy elismerés illetne meg egy vezetőt, ha így gondoskodna saját utánpótlásáról. Azóta az utódok közül is többen előbbre léptek, és nem lehet méltóbb feladatuk annál, mint hogy munkájukat Gábor professzor szellemében, az Ő szigorú következetességét követve folytassák, az általa fémjelzett színvonal elérésére, fenntartására törekedjenek. 

Épités- Épitészettudomány XXIX (1-2) 35-40

\title{
GÁBOR LÁSZLÓ SZAKIRODALMI MUNKÁSSÁGA
}

\author{
SZÉLL MÁRIA
}

egyetemi tanár

Gábor László szakirodalmi tevékenysége, ez irányú müködése az építészettudomány számára meghatározó volt, s mértékadó ma is.

Gábor László oktatói és tudósi pályafutását több mint másfél évtizedes szakmai gyakorlat és átlagon felüli humán műveltség alapozta meg. Kiépítette az épületszerkezettan kapcsolatát a természettudományokkal, épületfizikai alapokra helyezte, objektív tudománnyá fejlesztette azt. Az épületszerkezetek konstruálásának középpontjába mindig az épületet, az építészeti szándék megvalósítását állította, és nem a szúk értelemben vett technikai, technológiai megoldásokat.

Időrendben áttekintve munkásságát, első szakkönyve az 1952-ben megjelent háromkötetes Tetöfedések és fémlemezmunkák volt. A négykötetes Épületszerkezettan keletkezésének évei: 1959, 1962, 1968 és 1977. A könyv csaknem 20 évet foglal le a 32 évre kiterjedő tudósi pályafutásban. A Díszlakatos munkák című könyv befejezetlen kézirat maradt.

Társszerzőkkel megjelent művei: Az információ továbbitása és vétele az iparositott épitésben (Párkányi Mihállyal) 1979-ben, az Energiagazdálkodás az épitészetben (Zöld Andrással) 1981-ben, A nemtektonikus épités alapvetö szerkezetelméleti kérdései (Párkányi Mihállyal) 1985-ben készült el.

Nevéhez szakcikkek és kortárs tudósokat valamint múvészeket méltató írások is füződnek, s máig hatóak elméleti fejtegetései. Ezek sorából - átfogó, szintézisteremtő jelentőségük miatt - ki kell emelni akadémiai székfoglaló előadásait.

Az első nagy könyv a Tetőfedések és fémlemezmunkák címü 500 oldalas mú, mely a terjedelem 50\%-át meghaladó ábramennyiséggel, 10 fejezetben foglalja össze mondanivalóját. A szerző az előszóban céljait így fogalmazza meg: „,E könyv az épület atmoszférikus hatásoknak legjobban kitett, kényes, könnyen meghibásodó, és gyakorta csak nagy nehézségekkel, illetve komoly költséggel javitható szerkezeteivel ...foglalkozik. Célja e szerkezetek helyes tervezésének, szakszerü elkészitésének megkönnyitése, az ezekkel foglalkozó szakemberek munkájának segitése. ... Az egyes fedési fajták és azokon belül a különbözö fedési módok 
tárgyalása a könnyebb áttekintés és egyszerübb összehasonlitás kedvéért szigorú és következetes rendszerben történik."

A téma tárgyalása a rendeltetés tisztázásával indul. A követelmények sora - a csapadékbiztosság és csapadékelvezetés kérdéseitől az esztétikai minőség igényének megfogalmazásáig - ma sem szorul kiegészítésre. A fedések rendszerezése a rendeltetés, a szerkezeti jelleg, az anyag, a hajlásszög, a tartósság és karbantartás mértéke alapján máig helytálló.

A könyv a tetőfedések elveit a hajlásszög függvényében csoportosítva tárgyalja. A lejtés anyag- és technológia-függő, ezek pedig az elmúlt 50 év alatt alapvető változáson mentek keresztül. A lejtésképzésnek a könyvben megfogalmazott általános elvei mégis időtállóak. Más kérdés, hogy egyes anyagok, pl. a papírbetétes lemezek tiltó listára kerültek, a szurokragacs-fedés fogalmát pedig jószerivel nem is ismerjük ma már, és másként gondolkodunk a külső és belső vízelvezetés alkalmazhatóságáról is.

A fedések egy részének - pl. a kavicsolt bitumenes fedéseknek - ismerete azért fontos, mert felújításuk jelenleg ad feladatot. Más részük - pl. a kéve- és fafedések - a múemlékvédők számára érdekesek, de ökologikus szempontból is figyelemre méltóak. Az üvegbeton tetőkről ma sem tudunk sokkal többet, igaz, hogy csaknem fél évszázadnyi szünet után mostanság kerülnek újra az érdeklődés homlokterébe. Az egyes fedések bemutatását az alkalmazott anyagok és szerszámok, valamint a készítés munkamenetének leírása vezeti be. Az ábrákkal részletesen illusztrált szerkezeti megoldásokat az anyagszükséglet és a költségvetési szöveg mintája egészíti ki. A tetőszerkezetek bemutatása így teljes volt, a tervezés és kivitelezés valamennyi résztvevője megtalálta benne a szükséges információkat. A harmadik kötetet a fedések - táblázatos formájú - összehasonlítása zárja le. Megállapítható, hogy a táblázat a tervezés során elengedhetetlen döntéseket egyértelmú utasításokkal segítette.

Érdekes tanulmány a könyvnek a témájában azonos, de 16 évvel későbbi, Épületszerkezettan III. kötetével való összevetése. Ez utóbbiban bizonyos túlhaladott fedési módok már nem szerepelnek, lényegesen szúkszavúbb az anyag- és technológiai leírás, hiányzik a költségvetés, részletesebb azonban az elméleti megalapozás.

Az életmű gerincét alkotó négykötetes Épületszerkezettan alapmű, s máig használt tankönyve az építész- és építőmérnök képzésnek. A szerző alkotói szándékát az első kötet előszavában, 1959-ben így foglalta össze: , Az épületszerkezettan feladata az épület összes szerkezeteinek oktatása, a szerkesztö-, szerkezettervezö készség kifejlesztése, a ... szükséges ismeretanyag, mesterségbeli tudás és szakmai müveltség megadása. A könyv módszere: törekszik a fokozatosságra, az összefüggések kimutatására és igazolására, az összehasonlitásra, mint az értékelés és kiválasztás alapjára, és a leggyakoribb, a legalkalmasabb és legkorszerübb kiemelésé- 
re. ... Az oktatás, nevelés célja tehát világos, egyértelmü, ugyanakkor azonban az épitészet, épités és épitéstudomány teljes területe az átalakulás, változás, a nagyiramú fejlődés időszakát éli. Más a tartalom, más a kifejezés és a formálás is. A régi mellett forradalmian új anyagokból, új szerkezetekkel és új eljárásokkal épitünk. A múlt hagyományos szerkezetei egyre jobban értelmüket vesztik, az emberi hangyaszorgalom munkáját egyre inkább gépek munkája váltja fel. A feltörö új kiszoritja a régit, de az új még nem általános, még nem teljesen kiforrott, még csak kisérlet-sokszor még ki sem próbált-, és eredete is visszanyúlik a régibe. A régibe, mellyel unos-untalan találkozunk. Amely még házaink anyaga, szerkezete, amelyet még sokáig foltozunk, javitunk, amelyet tehát ismerni kell. Tanitani és tudni kell a régit, de még inkább az újat. Ismerni kell a múltat, de látni kell a fejlödés irányát."

Hogyan írt a falakkal kapcsolatosan?

„Az elemi fal megismerését a fal összetettebb, tágabb értelmezésü tárgyalása: az épület falának, mint szerkezetnek vizsgálata követi. E vizsgálat az épületszerkezeti (elsösorban hö- és hangtechnikai) és tartószerkezeti követelményeknek együttes teljesitésén alapul, és az épitészeti igény kielégitésével, a gazdaságosság biztositásával válik szerves egésszé."

Hogyan bővítette a vizsgálódás körét és vont le általános következtetéseket a szerkezeti rendszerek tárgyalása során?

„A társadalom nagyszabású feladatainak megoldásához, a társadalomban élök sokrétü és szerteágazó tevékenységéhez a különbözö rendeltetésü, jelentőségü, számú és értékü épületek egész tömegére van szükség. ... a rendeltetés és követelmények azonosságából a funkció azonossága, az alaprajz hasonlósága, a méretek hozzávetöleges egyezése, következésképpen az anyagok, szerkezetek és szerkezeti rendszerek jellegazonossága adódik. ... A fentiek alapján természetes tehát, hogy épitési és szerkezeti rendszeren a hasonló tulajdonságú anyagokból nagyjából egyezö módon készitett szerkezetek lényegében azonos elrendezése értendö."

Gábor László felismerte az iparosított építés korlátjait, és például a paneles építési rendszert „az épitészeti és szerkezeti tervezés vonatkozásában: ... a funkció némi háttérbe szoritásával, túlságosan merev, szoros és átalakithatatlan alaprajzi elrendezéssel, kissé egyhangú épitészeti formálással és kötött telepitési renddel" jellemezte. Ez a szöveg 41 éve íródott. Azt, hogy ebből mi a máig érvényes s mi az, ami érvényét veszítette, szakemberek számára szükségtelen magyarázni.

Gábor László Párkányi Mihállyal közösen végzett kutatásainak eredménye két kötetben jelent meg. A második kötet, A nemtektonikus épités alapvetö szerkezetelméleti kérdései megjelenését professzor úr nem érhette meg, de e témában közösen írt cikkük a Periodica Polytechnica Architecture 1979-es számában már napvilágot látott. A mű - a Sámsondi Kiss Béla megalkotta szövetszerkezetes építésmód ötletéből kiindulóan - újszerü építési rendszert s új eszmerendszert alkotott 
meg. A kiindulásként felvetett kérdések - van-e a modern építészetnek létjogosultsága; alkalmas-e az építőipar (globális szinten) az igények kielégítésére; mik a gyökerei a polarizálódásnak, az építészet kontra építóipar dichotómiájának - ma is időszerűek.

A szerzők állítása szerint a jövő építészete az iparosítás és e dichotómia feloldása nélkül nem létezhet. A fejlődést kutató tudományos extrapoláció célkitüzése kettős: lamint

- az építés-építészet objektív világáról alkotott tudati kép továbbfejlesztése, va-

- az építészetnek az iparosításon alapuló kiteljesítése, a gyártás nyílt múveletté tétele.

A könyv írói a közvetett extrapoláció elvét követik, s az építést a technika egyetemes világa részeként fogják fel. A különböző technikák, technológiák közös jellemvonásait elemezve érkeznek el a Gutenberg elvig. Arra a felismerésre jutnak, hogy a tervezés-gyártás-összeállítás hármas múveletéből összetevődő építés a beszéd-írás-nyomtatás áttétele segítségével modellezhető. A Gutenberg-elvü építésben a gyártás legkisebb eleme, az elemi részecske nemtektonikus (nincsen teherbíró képessége, s nincs közvetlen stabilitása sem), nem bír önálló értelemmel, vagyis mint írásjel a betünek felel meg. Amíg a hagyományos és az iparosított építés, mint múvelet a tektonika axiómáján alapul, a nemtektonikus rendszerek szakítanak ezzel az axiómával és azt a felületelvvel helyettesítik.

A nemtektonikus építés kimunkálásával a szerzők szándéka az volt, hogy a fejlődő országok építési szükségletét kielégíteni képes építési módot alkossanak.

A technológia oldaláról megfogalmazott követelmények:

- iparosítottság a tömeges igények kielégítésére;

- meglévő alapokra, helyi anyagokra épülés;

- igazodás a különböző építészeti és funkcionális igényekhez;

- megfelelés az eltérö földrajzi és klimatikus feltételeknek;

- flexibilitás, nyílt rendszerüség.

A társadalmi aspektusok:

- kis létszámú szakemberigény;

- szakképzetlen munkaerő alkalmazhatósága;

- „self-help” módszerek elősegítése.

A gazdasági szempontok:

- ne legyen kiépített infrastruktúrához kötve;

- képezzen átmenetet a jövő építési módjai felé;

- legyen költségkímélő.

A problémafelvetés a maga idején újszerü, elöremutató volt. Mi valósult meg mindebből? Néhány kísérleti épület. Elvesztette mára a program aktualitását? 
Nem. Ezt bizonyítja ugyanezen igények egyre sürgetőbb megfogalmazása nemzetközi építészeti fórumokon, CIB kongresszusokon kiadott Agenda-kban. Igaz ez akkor is, ha a javaslat 20 év után újragondolásra szorul.

Párkányi maga így ír erről: „,... meddőnek bizonyul minden utópizmus, minden konkrét megfogalmazása a jövőnek, mert nem tud kellöen számolni a változással, ... korunk épitészetének legmozgékonyabb mozgásformájára, a technológiára támaszkodva keresni kell a jövö »tégláját", vagy ha úgy tetszik, a jövőnek azt az építési módját, amely az állandóan változó követelményeket hajlékonyan és idejében nyomon tudja követni."

Az információ továbbitása és vétele az iparositott épitésben címủ mủ megjelenési éve 1979. A könyv a szokásostól eltérő, vékony, finom és összetett épületszerkezetek ábrázolásának problémájával foglalkozik. A szerzők erre a Monge-féle képi ábrázolást alkalmatlannak ítélik.

Az eszmerendszer a nemtektonikus építéshez kötődik. A nyílt rendszer végtermékét - az épületet - a gyár „,nem látja”, ezért tégláinak gyártása vakgyártásnak nevezhető. A vaktervezés az építészeti gondolatot nem képi, hanem információs vonatkozásban tárja fel a mérnöki megismerés elött, a térbeli, háromdimenziós üzenetet kódolja. Ezt az üzenetet hálók és jelek összefüggő rendszere alkotja. Az építmény megvalósításához szükséges közlés egyrészt a gyártást, másrészt a helyszíni összeállítást szolgálja, és tartalmaz rajzi, valamint szöveges elemeket is.

Ez az elmélet a számítógépes tervezési technikák kiterjedt alkalmazását megelőző korban elöremutató volt. Az, hogy ma hol van e gondolat helye az építészeti információk közlése területén, külön tanulmány tárgya lehet.

Az Energiagazdálkodás az épitészetben címü, Zöld Andrással közösen írt kötet az első energiaválság után nyolc évvel, 1981-ben jelent meg.

A könyv az alapfogalmak tisztázása után a határoló szerkezetek hőfizikai természetével, a terek, tércsoportok állapotviszonyaival, majd az épületek energiamérlegével foglalkozik. A mondanivalót a gyakorlati következtetések megfogalmazása zárja, amely az alábbiakkal foglalható össze:

- az építési feladatok tovább növekednek;

- az épületek használati értékét és minőségét javítani kell;

- az energiával takarékoskodni kell;

- az energiagazdálkodás szempontjainak teljesítését az igényszint-növelés nehezíti;

- a kitüzött cél - a kedvezőbb energiamérleg - a szóba jöhető (építészeti, szerkezeti, gépészeti) lehetőségek kihasználásával elérhető;

- ehhez ismeretekre, mérlegelésre és felelősségérzetre van szükség;

- mindez megfelelő építéspolitikai elgondolás és müszaki szabályozási rend nélkül elképzelhetetlen. 
A hatékony energiagazdálkodás érdekében szükség volt a szerkezetek épületfizikai elemzésére, értékelésére. Ezt a könyv - az épületeket a kis- és nagyteresek csoportjára bontva - jól áttekinthető táblázatban adta közre.

Szabó János akadémikus a könyv utószavában ezt írja: az épületek ,, hovatovább okosan megszerkesztett szép gépek, melyek ... az emberi élet minöségét szolgálják és a szép iránti vágyához adhatnak monumentális teljesülést. Akármelyik feladatot tekintjük, használati értékröl van szó, amely a társadalom tulajdonában lévö mindenkori vagyon pillanatnyi értékének több mint kétharmadában ölt testet. Létrehozása, élvezhetö müködtetése sok szorgos, ügyes kezet, okos, elörelátó fejet igényel. Nekik szól ez a könyv."

Gábor professzor halálakor közvetlen munkatársa és barátja, Párkányi Mihály a Müszaki Tudomány lapjain e szavakkal emlékezett meg róla: „A hazai épületszerkezettant - amely ... alig volt több mint a piac kínálta szerkezetek puszta leírása-objektív kritériumokra alapozott tudománnyá fejleszti. ... Az épületszerkezettudományt a szerkezettervezés, épülettervezés eszközének tekinti és müveli ... Gábor László alkotói és kutatói munkásságának különös - és épités- épitészettudományunkban egyedülálló - ismérve, hogy ö életmüvét nem részletekböl épitette fel, hanem azt eleve összefüggö egészként anticipálta. Ö sohasem valamilyen részt ragadott ki önkényesen, hanem mindig az agyában már eleve megalkotott Egésznek egy alkotóelemét dolgozta fel és mindig úgy, hogy annak valamennyi összetevöje végső fokon egy »időtlen « Épitészet nem osztható egésze felé mutasson."

Tevékenységének méltatása szebben ma sem fogalmazható meg. Az elmondottak megerősítik a bevezetőben tett kijelentést, mely szerint Gábor professzor szakirodalmi munkássága - különösen annak elméleti alapvetése - ma is aktuális. Tankönyvei az épületszerkezettan oktatásának gerincét képezik, s még hosszú ideig nélkülözhetetlenek lesznek. 


\section{GÁBOR LÁSZLÓ SZAKIRODALMI MÜVEINEK JEGYZÉKE}

Összeállította:

SZÉLL MÁRIA

egyetemi tanár

\section{Szakkönyvek:}

1. Tetőfedések és fémlemezmunkák I-III. É. M. Építőipari Könyv- és Lapkiadó, Budapest, 1952.

2. Épületszerkezettan I. Tankönyvkiadó, Budapest, 1960.

3. Epületszerkezettan II. Tankönyvkiadó, Budapest, 1964.

4. É Ë̈letszerkezettan III. Tankönyvkiadó, Budapest, 1972.

5. Épületszerkezettan IV. Tankönyvkiadó, Budapest, 1979.

6. Diszlakatos munkák (kéziratban)

Szakkönyvek társszerzökkel:

1. Párkányi Mihállyal: Az információ továbbitása és vétele az iparositott épitésben. Bevezetés a vaktervezés elméletébe. Akadémiai Kiadó, Budapest, 1979.

2. Zöld Andrással: Energiagazdálkodás az épitészetben. Akadémiai Kiadó, Budapest, 1981.

3. Párkányi Mihállyal: A nemtektonikus épités alapvető szerkezetelméleti kérdései. Akadémiai Kiadó, Budapest, 1985.

\section{Szakcikkek:}

1. Az építőipari költségmérés tudományos módszere.

2. A különböző szintszámú lakóépületek szerkezeti és gazdasági vizsgálata, az optimális magasság megállapítása.

3. A különböző típusú lakóépületek müszaki és gazdasági összehasonlító vizsgálata.

4. Quelques problémes relatifs de la protection des toits contre I' action thermique et la condensation des vapeurs. ÉKME Tudományos Közlemények, 1963. 
5. Korszerü víz- és nedvesség elleni szigetelés (társszerzőkkel). OMFB, Budapest, 1963.

6. A 100 éves építészmérnök képzés története. Periodica Polytechnica Architecture, 1972. 3-4.

7. Az építészet és az építészettudomány feladata, jelentősége, gondjai. Magyar Tudomány, 1972. 434-440.

8. Kovács Margit állandó gyüjteményének katalógus-előszava. 1974.

9. Major Máté köszöntése. Periodica Polytechnica Architecture, 1974. 1-2.

10. Széll László: Építéstechnológia I. című könyvének ismertetése. Müszaki Tudomány, 1974. 479.

11. Az építészeti tervezés és az építési technológia szerepe, összefüggése az alkotásban (székfoglaló előadás). Épités- Épitészettudomány, 1974. 203-214.

12. Szeretném a lakásépítés egynéhány nagyon időszerü tervezéselméleti kérdését megvizsgálni. Magyar Tudomány, 1974. 82-84.

13. Építészet, szerkezet, gyártás. Épités- Épitészettudomány, 14. 1975. 275-283. Architecture, structure, manufacture. Periodica Polytechnica Architecture,

14. Az iparosított építés építészeti problémái. Megnyitó az MTA 1976. május 20-21-én tartott ankétján. Épités- Épitészettudomány, 1977. 3-8.

15. Az építés-építészettudomány helyzete az építésben, az építés iparosításában. Magyar Tudomány, 1978. 815-822.

16. Széll László 1903-1976. Müszaki Tudomány, 1977. 9-11.

17. Sun Shields. Periodica Polytechnica Architecture, 1978. 1-19.

18. The Theory of Blind Design (Párkányi Mihállyal). Periodica Polytechnica Architecture, 1979. 1-34.

19. Építészet és energiagazdálkodás. Gondolatok és beszámoló egy sajátos megoldást kereső komplex kutatás és kísérlet tapasztalatai alapján és ürügyén (Zöld Andrással). Magyar Tudomány, 1979. 842-848.

20. Hétköznapok és csodák. Az építés világa és tudományos sajátszerüsége (székfoglaló előadás). Müszaki Tudomány, 1979. 283-293.

21. Technológia, iparosítás, építészeti környezet. MTA Müszaki Tudományok Osztályának Kiadványa, 1981. 1-11. 


\title{
GÁBOR LÁSZLÓ HATÁSA A JELENKORI MAGYAR ÉPÍTÉSZETRE
}

\author{
FINTA JÓZSEF
}

akadémikus

Nem vagyok emlékező típus - vagy helyesebben szólva, emlékezetem igen szelektíven múködik. Egészen különösen bonyolult nyelvezetủ versek, memoriterek gyermekkorom óta ott ragadtak agyam valamelyik kanyarjában, ám eseményeket, neveket, adatokat, dátumokat napokon, órákon belül elfelejtek. Arc- és névmemóriám agyam két külön féltekéjében bújhat meg, jószerivel alig találkoznak egymással, s emiatt komikus helyzetek sorába sodródom. Azokat azonban, akik életem részét képezték valamikor, akik pályámra komoly hatást gyakoroltak, akiket becsültem és szerettem, azok nem emlékezetem múlékony részei, hanem szívemben, lelkemben spiritualizálódtak; egy-egy gesztusuk, hangjuk, tekintetük, mosolyuk, s persze elmosódott, szfumátós színezetủ megannyi cselekedetük - nos, ez már mind én vagyok, véglegesen. Gábor Lászlót is saját részemmé sajátítottam ki. Mégis, amikor e rövid emlékezésre felkértek, pánikba estem - épp emlékezetem előbb említett szelektív technikája miatt. A legkevésbé sem vagyok az adomák, a mesélések mestere, s hiába törtem a fejem olyan konkrét, és nagy társaság előtt is elmondható történetek után, amelyek bárminemú újdonsággal szolgálhattak volna a mindannyiuk, mindannyiunk által ismert BUBU-képhez - akár egy minimális ecsetvonás léptékéig -, azért vállaltam hát ezt az elvontabb s általánosabb kiselőadás-témát, címet.

Különben csupán annyit mondhatnék - bőbeszédűen -, hogy volt egy ember, kedves professzorom, akit becsültem és szerettem, s akitől ezeket az érzéseket viszonzásul én is megkaptam, és aki - s eme cselekedetét máig sem értem igazán Major Mátéval együtt - szinte kényszerrel és fókuszált energiával - akadémikussá kent fel. Szép ajándéka volt a sorsnak a mi generációnk számára, hogy egy egyén és nemzet számára egyaránt szerencsétlen, lelket nyomorító korban építész hallgatóként olyan európai léptékú mestereink lehettek, mint Csonka Pál, Pogány Frigyes, Weichinger Károly, Rados Jenő, Bardon Alfréd, Major Máté és Gábor László (s messze nem teljes a névsor). Gyönyörü, és igen hasznos kompenzáció volt ez - minden más nyomorúságunkkal szemben -, máig ebből a perszonális útravaló- 
ból élünk. Az én egész genetikai örökségem, neveltetésem, családi hátterem, érdeklődési köröm, egyértelműen humán tartalmú volt, s a református gimnázium, amelybe hét évig jártam, ugyancsak ilyen szellemet oltott belém. S noha a reál tantárgyakkal soha semmi bajom nem volt, a Mủegyetem mérnöki habitusát igencsak meg kellett szoknom - mondjuk inkább úgy - szenvednem.

$\mathrm{S}$ bevallom, az épületszerkezettan, mint tantárgy sohasem lett szerelmem tárgya; akkoron, az 1950-es évek derekán végletesen nem (hozzáteszem, a statikával, a tartószerkezetekkel ugyanígy voltam). S hogy épp e tudományok, e szakmák, e mesterségek a legperelhetetlenebb szervességgel épültek bele építészetem mívelésébe - önmagamtól, s munkatársaimtól igen keményen elvárt követelményként, mindenkor kötelezően megfejtendő feladványként - nos, ezt szinte kizárólag Csonka és Pelikán professzor uraknak, és sokszorosan aláhúzottan, Gábor Lászlónak köszönhetem.

Minden egyetemi hallgató, ha normális, s nem betegesen eminens, bizonyos szelektív tudásvágya mellett - a tantárgyak zömét tanulván - életét a megúszás trükkjére építi, $\mathrm{s}$ a legtermészetesebb módon nem konglomerálódik benne össze egy matériává, egy szerkezetté az épülettervezés minden eleme, összetevője; még nem tudatosulhat benne az a fontossági sorrend, az a szakmai hierarchia, amely egész építész életét végig fogja kísérni.

Gábor László példátlan hatása, léptéke éppen abban a képességében rejlett, ahogyan el tudta adni hallgatóinak az épületszerkezettant. E képességének érvényre juttatásában nagymértékben segítette tervező habitusa (azaz tudta, hogy MI A HÁZ, hogy a tervezés struktúrájába, folyamatábrájába miként épül bele a szerkezetalkotó, DESIGN-teremtő felkészültség), és persze utolérhetetlen charme-ja, pedagógusi adottságai, nem elhanyagolható színészi kvalitása, rajztudása, de mindenekelőtt professzori-tervezői-konstruktőri tudásának kikezdhetetlen biztonsága. $\mathrm{S}$ ne feledjük, milyen szerves része volt pedagógusi munkásságának a - csak így, ekként nevezhető - BUBU-i humor, amely a legálmosabb, legalacsonyabb vérnyomású hallgatót is ébren tudta tartani az előadás végéig. Ezeken a „szeánszokon” mindig történt valami csoda, valami akció, „elhullt” valami szólás, valami megjegyzés, amely később (már az óra után) beszédtéma lett, s némelyikét az IDÖ legendává nemesítette.

Gábor Lászlótól tudtuk, tanultuk, értettük meg, hogy a SZERKEZET minősége, állékonysága, időtartama, javíthatósága, esztétikai értéke nem csupán szakmai, de MORÁLIS kérdés is. Sokan és sokszor támadják a Múegyetem igen erős mérnöki habitusát, én büszke vagyok erre a karakterre. Vallom, hogy a tervezés olyan szolgálat, olyan komplex szolgáltatás, amelynek minőségtartalma elsődlegesen használati értelemben, e tulajdonságaiban, tehetségében nyilvánul meg, s e használhatóság egyik legfontosabb faktora - a funkcionális összetevő mellett - az épület 
szerkezeteiben materializálódott, megalapozott BIZTONSÁG, s persze hangsúlyozottan, a konstrukció szépsége!

Abban az időben, amikor Ő tanított, a magyar építőipar meglehetősen alacsony színvonalon állt, s hogy miért, nem kell Önöknek magyaráznom. Nem tagadom, hogy azidőben sokunkban, akik legalább a folyóiratok böngészése szintjén némi képet formálhattunk magunknak az akkori nyugat-európai, amerikai építészet színvonaláról, ezen építészet szerkezeti etalonjairól, az északi példák, jelesül az Alvar Aalto iskola gyönyörüségeiről, a klasszikus modern akkor még létező nagyjainak munkáiról, s miközben ádáz elméleti vitákat folytattunk Le Corbusier, Wright, Gropius, Mies van der Rohe, Alvar Aalto igazságáról, néha bizony földhözragadt, elavult szerkezeti példáknak tekintettük azokat a falszerkezeteket, boltozatokat, kettős gerébtokos ablakokat, ácskötéseket, lemezfedéseket, amelyeket a professzor Úr előadott, rajzolt $-\mathrm{s}$ kollokviumain oly precízen megkövetelt $-\mathrm{s}$ amelyeket (egyébként máig használható) gyönyörü könyveiben közreadott.

Ma már tudom - s tudjuk mindannyian -, hogy ez a szépségesen komoly színielőadás másról szólt, mint az ablakok szerkezeti részelemei millimétereinek memorizálásáról. Szinte mindegy volt számára, hogy milyen régi és új példák során mutassa be nekünk azt, amit a szerkezetnek, az épületek megannyi részelemének, minden molekulájának TUDNI KELL, s hogy ez a TUDÁS, ez a tervezői képesség anyagiasult formájában milyen módon áll össze házzá (állt össze a történelmi, stiláris korok konstrukcióiban s a jelenben, és viselkedik, konglomerálódik össze ugyanilyen módon mindenfajta jövőben is). Gábor László, az építész, a mérnök, a professzor, az ember, a színész, a LÉPTÉK, az ETALON, ekként üzen a mának így nevelt minket, s így neveli a jelent is - a szerkezeti tudás becsületére. Az a KOR amelyben Ố élt, s amelyből Ő jött, még nem tett különbséget, nem ácsolt mesterséges palánkokat az álmodozó, kreatív ARCHITEKT, s a szerkezetekkel bíbelődő KONSTRUKTŐR közé. Öszintén szólva, nem tudom, hogy ez a konstruktőri rang - amely egykoron magasabban állt, mint a „müépítész” - miként és mikor fosztatott meg valódi tartalmától, szerepe súlyosságától és fontosságától, anyagi és szellemi megbecsülésétől.

Ma, amikor - Gábor László korával összevetve - az építészet, az építőipar, az építéstechnológia olyan fantasztikus eszköztárral rendelkezik, olyan gazdag konstrukciós, anyaghasználati háttérrel bír, amikor az építész szinte nem tud olyan formát, olyan teret, olyan DESIGN-részleteket kitalálni, amit az IPAR ne tudna követni, nos ma még fontosabb lenne visszahelyezni trónjára a némiképp hatalmafosztott SZERKEZETI TUDÁST és MÉLTÓSÁGOT, s elismerni a specialisták korában ezt a szakmai elhivatottságot. Némi szomorúsággal tapasztalom, hogy az általam ismert, netán stúdiómban dolgozó, fiatal építészek csupán átmeneti kényszer-állapotnak tekintik azon funkciójukat, beosztásukat, amikoris a HÁZ részelemeivel foglalkoznak. Nem érzik, nem értik igazán, milyen fontos ALKOTÓIK 
ők az épületnek, tervnek, s hogy munkájuk miként szervül, miként nemesül önálló értékké az építmény egészében.

A magyar építészetnek hatalmas csatát kell vívnia a jövőben KÖZÖS EURÓPAI pozíciójáért, valójában ez a küzdelem már rég elkezdődött. Ezt a kegyetlen egzisztenciális harcot, ezt a tülekedést a versenypályán akkor lehet reményteljesen megvívni, ha az a komplex építészeti MINŐSÉG (használati-szerkezeti-formai érték), amelyet megteremtünk és felkínálunk - ÁRUKÉNT -, többet ér más, nálunk gazdaságilag talán jóval erősebb, társadalmilag stabilabb nációk produkcióinál. Ha felkészültségünk érdemesít erre a versenyre (úgy hiszem, igen), és e téren is halovány nemzettudatunk stabilizálja majd ebbéli önérzetünket - még nyertesek is lehetünk. Erre bíztathat minket Gábor László példája, életútja, örök optimizmusa, - ne okozzunk Neki csalódást! 


\title{
GÁBOR LÁSZLÓ MƯHELYISKOLA
}

\author{
PAPP ANDRÁS
}

„, Kidőlt keresztfának nem köszön már senki.”

Az egyszerű magyar ember bölcsessége szól hozzánk ezekben a szavakban. Így figyelmeztet a gyorsan elrohanó életre, mulandóságunkra, és a még gyorsabb feledés, a végső elmúlás tragikus valóságára. Csak ez a rövid, néhány évtizedes földi életpálya adatott nekünk arra, hogy nyomot hagyjunk a kőben vagy az emberi emlékezet futóhomokjában. Hangunk elhalkul, árnyékunk halványul az egyre újabbak, a mindig fölénk törekvő új generációk fényében. Így van ez rendjén, mégis, milyen szomorúan kevés az emberi élet.

Az eltávozott öregek köszöntésére, a visszatekintésre csak azok képesek, akiknek nem kell félniük a megmérettetésben, akik emelt fejjel, de mélyről induló, hosszan őrzött gondolatokkal hajolhatnak meg mestereik emléke előtt. A nemes lélek felemeli, újra felállítja a földre hullott keresztet, hogy meghajolhasson előtte. Az Önök megtisztelö társaságában ennek a nemes emberi gesztusnak vagyunk ma tanúi és részesei. A Gábor Lászlóról elnevezett iskola képviseletében örömmel és tisztelettel köszöntöm a Gábor László Emlékülés résztvevőit.

Szeretettel köszöntöm Önöket úgy is, mint felnőtt életem meghatározó partnereit: volt tanáraimat 30 év távlatából, müegyetemi hallgatói éveimből, idősebb kollégáimat és tanszékvezetőmet a felsőoktatásban, 23 év távlatából, győri főiskolai oktatói éveimből és jelenlegi munkatársaimat a Gábor Lászlóról elnevezett iskola vezetőjeként.

Megható és megtisztelő alkalom a mai nap számomra, mert ezen a napon, a Magyar Tudományos Akadémia falai között megvalósult az a felemelő, nagy találkozás, melyre az elmúlt évtizedben olyan sokan, annyi gondolatot, időt és konkrét munkát áldoztunk. Bemutathatom az iskolát, mely Gábor professzor úr szellemében, az általa és az Önök közvetítésével terjesztett, tanított szakmai elvek elfogadásával jött létre Győrben, 1995-ben.

Ezen a napon tisztelettel adózunk Gábor László élete és munkássága előtt, aki úgy búcsúzott el tőlünk, ahogy közöttünk élt: szellemi örökségét és anyagi javait lélekben és valóságban is a gyermekek gyógyítására, a fiatalok tanítására ajánlotta 
fel. E nemes gesztus részese a győri építőipari szakképző iskola, melyet szellemiségének követőjeként, személyes kezdeményezésem elfogadásával, az itt ülők nagy részének konkrét részvételével és támogatásával alapított Győr Megyei Jogú Város Önkormányzata öt évvel ezelött, 1995. július hó 1-jén.

$\mathrm{Az}$ iskola az idősebb és fiatal polgárok, mesterek, tanítók és tanítványaik együttmüködő közössége, melyet az elméleti és gyakorlati tudás átadásának és befogadásának, valamint az erkölcsös állampolgári magatartás kialakításának és fenntartásának kölcsönös társadalmi érdekei tartanak össze.

Az iskola megjelenési formája, az épület - szerencsés esetben - tükrözi annak különlegesen szép és nemes funkcióját. A tartalom nélküli épület homlokzata csak megtévesztő szándékkal üzenhet iskoláról, ahogy kiváló iskolák müködhetnek és múködnek is méltatlan körülmények között. Most, amikor az iskolát bemutatom, az épületre csak azért térek ki részletesebben, mert létrehozása, konkrét megépítése egy kiváló szakmai közösség részéről hitvallás és páratlan áldozatvállalás volt az építö- és faipari szakképzés érdekében.

Az 1990-es évek gazdasági változásainak rohamában, váratlanul és nagyon gyorsan omlott ránk a feladat, hogy a felszámolt vállalati gyakorlati helyekről elküldött tanulóink gyakorlati képzését, az elméleti és gyakorlati oktatás feladatait méltó és korszerü körülmények között oldjuk meg. Most, közel 10 év távlatából úgy vélem, hogy ezekben az években egyedül az iskola képviselte a folyamatosságot, az igényes biztonságot, a közösségi érdekek érvényesülését. A privatizáció rohamában elsősorban magunkra számíthattunk, és hátunkon cipeltük éveken át a saját, iskolai kivitelezésben vállalt beruházás feletti értetlenséget és bizalmatlanságot.

A változás éveinek sokszor rendetlen lendületében kivételes és kiváló partnerekre akadtunk az új tulajdoni viszonyok között feltörekvő építő- és faipari nagyvállalkozások között. Így az új iskola épületének szerkezetei és szakipari részletei híven tükrözik az építés időszakában aktív szakmai kapcsolatok mértékét. Iskolánk épületében megtalálható az 1990-es évek Magyarországán forgalomban lévő anyagok és szerkezetek egész sorozata. Gyártó és forgalmazó partnereink számára hiúsági kérdés volt a támogatás megoldása. Az építést - egyes, az iskolában nem tanított szakmákat érintő munkák kivételével - saját szakoktató kollégáink végezték, tanulói csoportjaikkal. Csak a tisztelet hangján szólhatok arról, hogy a 4600 $\mathrm{m}^{2}$-es létesítmény jó minőségű felépítése során úgy irányították cca. 600 fiatal munkáját, hogy építkezésünkön egyetlen tanulói baleset sem történt.

Amikor az új iskola első két üzemét használatba vehettük, az építő- és faipari szakterület levált az anyaiskoláról és elkezdte önálló intézményi életét. Hosszas megfontolás, ajánlások hosszú sora és széles körü egyeztetés előzte meg azt a névadóról szóló döntést, melyet javaslatunkra Fenntartónk elfogadott. Érthetően nagy volt a bizonytalanság, mert Gábor professzor nevét az építész szakma kiválóan is- 
merte, de személyes élményről egyre kevesebben nyilatkozhattunk. Nagyon fontosnak éreztük, hogy olyan személyiség nevével fémjelezzük tevékenységünket, akinek életpályája tiszteletre méltó oktatott szakmánk minden múvelője számára, mert csak így tudják feltétel nélkül elfogadni. Fontosnak éreztük, hogy szakember legyen, aki tanított, és tanításának érvényessége túlélte a mestert. Úgy gondolom, aligha találhattunk volna szélesebb szakmai és általános mủveltségủ jelöltet, népszerúbb és elismertebb építész pedagógust, tankönyvírót. Embert kerestünk, mert ebben a tanulói körben, melynek tanítása és nevelése feladatunk, nagyon sokszor van szükség empátiára, emberségre és olykor vaskos humorérzékre is. Embert kerestünk, mert a társadalmi-gazdasági átalakulás szerencsétlen veszteseinek tömege, szülőként partnerünk a gyermekek tanításában.

Dr. Gábor László és felesége messze mutató példával járt elől, amikor anyagi javaik örököséül a Heim Pál Gyermekkórházat nevezték meg.

Olyan tiszteletre méltó személyiséget kerestünk, akinek iskolája mellett, a Névadó halála után évtizedekkel sem mennek el köszönés nélkül volt hallgatói, kollégái, az Egyetem képviselői. Olyan személyt kerestünk, akinek neve és tevékenysége nem túnik el néhány év alatt a feledés homályában, de forrása, indikátora lehet kiváló emberi és szakmai kapcsolatoknak, és olyan felemeló élményeknek, mint ez a rendezvény is.

Amikor a Gábor László Mühelyiskola Építőipari Szakképző Iskola nevében az Építészmérnöki Kar Dékánjának, Petró Bálint professzor úrnak átadom a munkatársam, Szücs Ferenc által készített emléktáblát, azt kérem, hogy helyezzék el azt az Egyetem KII.32. előadótermében. Emlékeztesse a mindenkori építészhallgatókat az épületszerkezetek kiváló tanárára, és arra is, hogy a legkiválóbban tervezett épületszerkezeti csomópont sem valósul meg jól képzett mérnökök és kulturáltan dolgozó, szakmailag felkészült munkások együttmüködése nélkül! 


\title{
MEGEMLÉKEZÉSEK
}

\author{
GÁBOR LÁSZLÓ, AZ EMBER \\ BONTA JÁNOS
}

„Ilyen az ember. Egyedüli példány.
Nem élt belőle több és most sem él,
s mint fán se nő egyforma két-levél,
a nagy időn se lesz hozzá hasonló.”
(Kosztolányi Dezső: Halotti Beszéd)

A költő minden ember egyediségéről szól. Amit mond, sokszorosan igaz az olyan rendkívüli emberre, mint amilyen Gábor László - mindnyájunk szeretve tiszteli tanára - volt. Mi volt benne a különös, a rendkívüli? Nehéz erre válaszolni. Minden ember átláthatatlanul bonyolult, sokrétủ szervezet, telve ellentmondásokkal, megismerhetetlen titkokkal.

Az ember sajátos vonásainak egy részét őseitől örökli, más részét a kor és a környezet, amelyben él, alakítja ki s dermeszti véglegessé. Gábor László a világ, s benne Magyarország olyan hét évtizedét élte át, amelyben minden eddigieket felülmúló szörnyűségek, kegyetlenségek, nyomor és keserüség hihetetlen sưrítettségben és változatosságban fordult elő; teljes békében és biztonságban elnyújtózni szinte sohasem volt lehetősége.

Első gyermeki évtizedében az első világháborút, az azt követő zűrzavart, összeomlást, forradalmakat élte meg. Ma már tudjuk, hogy a gyermeki idegekbe - bár nem értik az okokat - életre szólóan beleégetődik az a feszültség és félelem, ami körülötte vibrál, s ami a viszonylagos béke éveiben sem képes teljesen lecsendesedni. Szüleimtől tudom, hogy a megcsonkított ország értelmiségének $-\mathrm{s}$ benne a zsidó értelmiségnek - milyen feszített versenyben kellett megküzdenie a munkáért, az életlehetőségekért.

Láttam egyszer Gábor pallértervét ez időből. Olyan volt, mint egy mákos tészta, tele számadatokkal, utasításokkal. Nyilvánvalóan Gábor László fölényes tudással, teljességre, tökéletességre törő teljesítménnyel állt helyt ebben a versenyben. Ezt szokta meg, ez vált vérévé, ezt próbálta átvinni a második világháború utánra is. A háború borzalmairól nem beszélek; Ő sem beszélt soha. De nem kétséges: tépett idegrendszere további sérelmeket szenvedett. 
A háború után néhány évre bizonyára feltámadt benne is a remény egy jobb jövőben, s lelkesen vetette bele magát a romváros ujjáépítésébe. De meddig tarthatott ez a remény? A Rákosi-kor az embert erkölcsileg-fizikailag megsemmisítő, cinikus, hazug bírósági színjátékai még a legfanatikusabb hívőből is kiégették a hitet. Gábor László addigra véglegesen tudatára ébredt annak, hogy Vörösmartyval szólva: „Az ember sárkányfog vetemény - nincsen remény, nincsen remény”.

Viszonylag békés időkben, a késői Kádár korszakban dolgoztam együtt Gábor Lászlóval: Ö rektorhelyettes volt, én dékán, Ö elnöke, én titkára az Építéstudományi Bizottságnak. Próbáltunk a Kar oktatási rendjén egy keveset javítani. Ebben az időszakban - Kádár szándékainak megfelelően is - a cél: az adott helyzet, az egyensúly megőrzése. A lusta, tohonya és stupid bürokrácia hozzátette ehhez a magáét. Murphy törvényeit alkalmazva erre a helyzetre: tenni kellene valamit, de ez kockázattal jár, válaszd a semmittevést. Ez az, ami homlokegyenest ellentétes volt Gábor nyugtalan, sőt türelmetlen tenni akarásával. Úgy érezte magát, mintha egy gumifalú zárt helyiségből próbálna kitörni. A falak kitérnek előle, de szabad levegőre nem juthat. Nap mint nap szüntelen feszültségben küzdötte magát előre. És gyakran az előrelépés utólag illúziónak bizonyult.

Hogyan lehet ennyi emlékteherrel, a bürokrácia polipkarjai között jókedvüen élni és dolgozni? Ez csodatett, Gábor László életének csodája. Menekülési útjai voltak. Az első a család és a baráti kör, a múvészettel telített kicsiny, de tökéletesen berendezett szép lakás a - nem tudom mennyi - úgy húsz-harminc eredeti Kovács Margit kerámiával. A másik menekülési lehetőség az olvasás. Habzsolta az angol nyelvű krimiket, amelyekben - mind a bün álcázásában, mind annak éles logikával történő felderítésében - azt a rendet találta meg, amit a valóságban nélkülözni kényszerült. A menekülési utak közül a központban mindenkor a tudományosszakmai munka állott, a tökéletes rendszerbe foglalt, négykötetes Épületszerkezettan munkálatai. Mások már méltatták, ez a szakkönyv éppolyan hüséges lenyomata az ő végtelen precizitásra, teljességre, tökéletességre törekvő egyéniségének, mint más nagyregények művész-alkotóié.

A szürke hétköznapok bugyutaságain angyali humora segítette át. Engem is „búbocizott” - még dékán koromban is. Sohasem sértődtem meg, mert éreztem barátságát, szeretetét. Amikor életveszélyes mütéten estem át, naponta izgatottan érdeklődött hogylétem felöl. A butuska hallgatókat is „,búbocizta”, de segítette őket a vizsgán, és ha hiába, melankolikusan zengő „búú”-val bocsátotta el őket. A legkülönfélébb emberekkel volt képes együttdolgozni. A teoretikus vénájú - de kissé talán fantaszta - Párkányi Mihállyal együtt írtak könyveket. Közös múveiket tökéletes stílusú, tömör bevezetésekkel tette helyükre. Tisztában volt Misi irrealitásba hajló, utópisztikus tehetségével. Amikor egy ízben Misit nála keresték, szokása szerint feltolta szemüvegét, és visszakérdezett: „Ön ugyebár a prófétaosztályt keresi - balra a folyosó végén.” Egy szép szál, szerecsen legényt - aki tanulás helyett 
széplányokat furikázott luxusautóján - így igazított el: „Téged nem azért küldtek ide sok pénzért, hogy capuccino-kat gyárts szériában."

Ilyen volt Gábor Bubu. Ma is magam elött látom, ahogy a második emeleti folyosón siet: sok dolga volt, és még sok lett volna, amit már nem tudott elvégezni. Az ellentét, az Ő maximális rendre, tökéletességre törekedő egyénisége, s e szörnyű világ, s később már nem iszonyú, csak tunya tespedő környezete között - mindenen felülemelkedni próbáló humora ellenére - korán felörölte fizikumát.

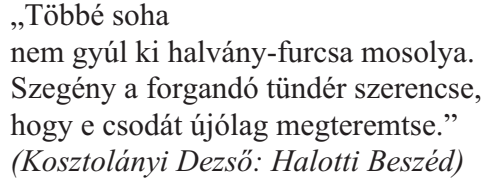

\section{A NEMTEKTONIKUS ÉPÍTÉS}

GARAY LAJOS

„A nemtektonikus rendszerek szakitanak a tektonika axiómájával, és azt a felületelvvel helyettesitik. A tektonika axiómája az épitöelemek egymásra helyezése, egymásra támasztása" - fogalmazza meg Gábor és Párkányi A nemtektonikus épités alapvető szerkezetelméleti kérdései címü könyvében.

A magam statikus szakmájának gondolatvilágában az építés teherhordó elemek rendszerré való összeállítását, összeépítését jelenti. Az elemek közötti axiális erőátadás fogalma felel meg a tektonika axiómájának. A tangenciális erőátadás, mely nyírt felületek mentén valósul meg, az erőátadásnak a nemtektonikus módja. Gábor és Párkányi megfogalmazásukban a tektonika axiómáját „felület-elvvel” helyettesítik, ami azt jelenti, hogy teherhordó rendszereket egymásra helyezett elemek helyett felületi elemekből is lehet építeni. Az utóbbi évtizedek, lassan évszázad eredménye az, hogy a mérnök által megtervezett feszítőerővel, egymás mellé helyezett elemek között teherhordó, nyírt kapcsolatot lehet létrehozni.

A felületelv másik megjelenési formája a felületelemekkel való építés. A nem teherhordó felületelemekkel való építés körébe tartoznak a zsaluzóelemekkel való építés legkülönbözőbb formái. E téren külön figyelmet érdemelnek a bennmaradó kis teherbírású zsaluzóelemek, melyek nagy felületüknél fogva saját síkjukban nagy nyíróerőket képesek átadni, és e mellett saját síkjukban merevségük is rendkívüli. Az axióma megvalósulásának szakmai feltételei vannak. A peremek mentén, sarkok környezetében elkerülhetetlen nagy szilárdságú részek kialakítása. A hajtogatott héjak és a szövetvázzal merevített rendszerek ezt kis anyagfelhaszná- 
lással valósítják meg. Ha a visszanyert zsalutáblákat is ide soroljuk, eljutottunk a monolit vasbeton építés új virágkorához, amelyet felületszerkezetek jellemeznek. A modern számítástechnikával egyszerübb egy vasbeton felületszerkezetet megtervezni, mint egy rudakból álló vázat.

Az előzőekben felsorolt lehetőségek célszerű kombinációja a mérnöki kreativitás érvényesülésének igen széles skáláját kínálja. Ezen belül minden alkalmazott anyag hatékony összeépítését is lehetővé teszi. A technológiai lehetőségek is óriásiak, és a törekvés, hogy kevés anyaggal, vagy újra hasznosítható anyagokból építsünk, ugyanúgy szolgálja személyes igényeink kielégítését, mint környezetünk védelmét.

Gábor László érdemének tekintem, hogy a modern technika igen szerteágazó területein kereste azokat az elveket, melyek az építés és építészet jövőbeni fejlődésének meghatározó jellemzői lehetnek. Lehetőséget teremtett olyan elméleti tanulmányokhoz és kísérleti építkezésekhez, ahol az adott ipari és gazdasági helyzet határáig el lehetett jutni. Mindehhez a legkülönbözőbb szakterületek egymásra hatásának érvényesülését fontosnak tartotta. Tisztelője volt a mérnöki kreativitásnak, az alkotás szabadságának, ami nagy emberi erény.

\section{A GÁBORI ÉLETMÜ TOVÁBBÉLÉSE BIRGHOFFER PÉTER}

Érdekes mesterség a miénk. Olyan, amelyben a nagy formátumú integráló személyiségek hatása szinte semmilyen más tudományterülettel nem összehasonlíthatóan jelentős. Mit is jelent számomra Gábor László munkássága? Számomra, aki talán az első olyan generációhoz tartozom, aki az egyetemi padsorokból már nem voltam - nem lehettem - résztvevője az ő előadásainak, Gábor László mindenekelött épületszerkezeti alapművében testesül meg - amin generációk nőttek fel, ami alapján ő egy olyan integráló személyiségként jelenik meg elöttem, aki belső hajtóerői által ösztönözve egy nehéz korszakban vállalta annak terhét, hogy a rendelkezésére álló „téglákból” felépítse a „házat”: egy szakma, egy tudományterület új otthonát. Megalkotta az épületszerkezettan alapmúvét, ami még ma is mindennapi hivatkozási alapul szolgál, aminek alapvető müszaki megállapításai még ma is igazak, s ami - nálunk elsőként - hangsúlyt helyezett az épületszerkezettan és a természettudományok közötti híd felépítésére.

Később, amikor a tanulóévek végeztével szerencsém volt az ő egykori - még mindig az ő szellemiségét viselő - tanszékén aspiránsként dogozni, szívtam magamba azt a gondolkodásmódot, ami ma is mindennapi munkám „ars poeticája”, 
vezérlő csillaga. Ez a gondolkodásmód - amit most szeretnék kiemelni, s amirôl már Finta József előadásában is volt szó - a következőkben foglalható össze: csak az az épület lehet építészetileg értékes, maradandó, ami nemcsak formavilágában, térstruktúrájában és funkcióteljesítésében, hanem magas színtủ müszaki megoldásaiban is értéket képvisel. Csak így lehet a tartalom és a forma egységes az építészetben. Rosszul megkonstruált épület hosszú távon nem képviselhet valódi építészeti értéket sem; a szerkezeti hibák lerontják annak esztétikai hatását, és zavarják müködését, s így nem képezhet térbeli keretet egy magasabb életminőségnek. Meggyőződésem, hogy ezen túlmenően a jól kialakított szerkezeti koncepció, a szakszerủen megoldott részletek építészeti értékhordozók is, míg a „megerőszakolt anyag" ezzel ellentétes hatású.

Mindez persze így - mint minden nagy igazság - triviálisnak tünik, de valójában ez a probléma a teljes XX. század építészetének fókuszában állt. Ezzel a kérdéssel foglalkozott építészeti oldalról már a Bauhaus-iskola is, és még inkább izgalmas ma, a technológiák és szerkezeti megoldások robbanásszerü fejlődésének korszakában: az anyagot ismerni kell ahhoz, hogy jól tudjuk alkalmazni.

Ha az építészet megfagyott muzsika, az építésztervező a zeneszerző. A zeneszerzőnek tudnia kell kottát írni, és az építészetben a tervek jelentik a kottát - a szerkezeti tervek is. Ahol a kotta nem kidolgozott, ott a végül felcsendülő zene is esetleges lesz.

Gábor László ezt a problémát közelíti meg a „magas építészet” szempontjából a „túIpartról”; az anyag és az épületszerkezetek oldatáról - a szerkesztési alapelvek meghatározásával.

Ezen alapelvek ma - az anyagok és a szerkezetek zavarba ejtó változatosságának korában - minden korábbinál fontosabbak. Csak ezek ismeretében, az alapelvek alapján tudunk a rendelkezésünkre álló számtalan lehetőség között világosan látni, közülük választani, a választott megoldást helyesen alkalmazni - mindent együttvéve: jó épületet konstruálni. Megállapításai - éppen e szemIéletmód miatt - még ma is igazak, $\mathrm{s}$ e gondolkodásmód a müszaki fejlődés rohamléptekkel történő haladása korában egyre időszerúbb.

Gondoljuk el, hány évtized telt el azóta! Gondoljuk el, mekkora teljesítmény ma az épületszerkezettannak csupán egy-egy vékony szeletét hasonló szinten feldolgozni! Gondoljuk el, mikor érik meg ismét az idő egy ilyen széles ismeretanyagot átfogó alapmú létrehozására! Kívánom valamennyiüknek, hogy életmúvük ilyen maradandó legyen! Kívánom valamennyiünknek, hogy legyenek közöttünk olyanok, akik ilyen maradandó nyomot hagynak a világban! 


\section{A GÁBORI GONDOLKODÁS IDŐSZERÜSÉGE} HORVÁTH SÁNDOR

1977 januárjában léptem át hallgatóként a Mủegyetem küszöbét, s a sors különlegessége folytán az első órám a K.II.32-ben, Gábor László épületszerkezetek előadása volt. Neve már ismerős volt, könyvei a technikumban is bibliaként tisztelt és rojtosra lapozott szakirodalmat jelentettek. Akkor még nem sejtettem, hogy később én is az akkor még elsődlegesen az ő nevével fémjelzett tudományterület aktív múvelője lehetek.

Az eltelt évek során, a szakipari technikák katedrán képviselt elmélete mellett ezek gyakorlatával is szoros kapcsolatba kerülve, az Épületszigetelők, Tetőfedők és Bádogosok Magyarországi Szövetsége szabályozási munkacsoportjaiban tapasztalhattuk a gábori gondolkodás időszerúségét. A bizottsági munka során a szakmai színvonal emelése, a szakoktatás szervezése jegyében született meg a „Lapostetők tervezési és kivitelezési irányelve”, mely szellemiségében tagadhatatlan örököse a Gábor-féle épületszerkezeti tervezés elméletének.

Az ismert kérdéssorok más szavakkal való megfogalmazása, illetve az azokra adott válaszok megszerkesztése a mai értelemben vett „teljesítményelvü tervezés".

Idézem kérdéseit:

- az elsö kérdés ,, mikor és miért van a szerkezetre szükség?”;

- a második kérdés , hová kerül?”;

- a harmadik kérdés „,hogyan kell kialakitani?”

A hivatkozott kiadvány és Gábor professzor úr szakmai munkássága közötti párhuzam nyilvánvaló: a tetőfödémek rétegfelépítése, a rétegek szerepének, feladatának, épületfizikai múködésének elemzése alapelveiben ma is helytálló. Az anyaghasználat, a hő- és páratechnikai folyamatok értékelése, azok állandósult vagy időben változó jellegének felismerése a nevével fémjelzett tankönyv adott fejezetének időszerűségét - az anyagok és az energetikai szemlélet jelentős változása ellenére - nem vonhatják kétségbe.

Idézett kérdéssora - mely tankönyvírói hivatásán, annak valamennyi kötetén végigvonul - egy gondolkodásmód. Egy módszer, mely a száraz adathalmaz lexikális tudása helyett problémamegoldásra nevel, és ezzel ma is alapja a teljesítményelvű szerkezettervezésnek, az ilyen szempontok szerint összeállított hasonló kiadványoknak. 



\title{
GÁBOR LÁSZLÓ ÉPÍTÉSZETI ALKOTÓ MUNKÁJA
}

\author{
VÖRÖS FERENC \\ egyetemi tanár
}

Nem sokkal a nagy gazdasági válság után, az 1930-as évek közepén, a pályáját kezdő építész egy bizonytalan, átalakuló építészeti környezet kínálta választások előtt állt. Megerősödött a Bauhaus irányzata, az új építészet visszavonhatatlanul jelen van, de a közvélemény még tartózkodó, bizalmatlan, újító elveivel még azonosulni képtelen. Az ipari fejlődés hallatlanul felgyorsul, a technikai lehetőségek széles sora is a változásokat sürgeti. Néhány korabeli publikációból vett idézettel talán pontosabb korkép rajzolható.

Walter Gropius 1934-ben az Építész- és Mérnökegylet előadó termében az új építészetről tartott előadását Márai Sándor író, újságíró egy cikkben elemezte. Szemrehányást tesz Gropius-nak saját szenvedéseiért - „amit akkor érez, amikor mai gondolkodású barátainak, mai értelemben berendezett lakásában vendég, szenvedö kortárs” - ahogy magát kifejezi. Idegesíti a lapos tető, ,, annál jobban érzi magát a fedél alatt, mentül csúcsosabb". Szakszerütlen, de nagy hatású cikkére a Tér és Formában több építész is válaszol, Becz Jenő ezt írja: , Az épitészet az a müvészet, amely soha nem lehet l'art pour l'art, mert gyökere az ember egyik legföbb életszükségletében található. Mikéntjét elsösorban az élet hétköznapi követelményei diktálják, müvészetének kifejezö eszközeit pedig a technika produktumai adják, amelyek a korral fejlödnek. ... A korszerü épitészet az arányok és tömegek müvészete, eszközei többek között a vasbeton, a vas és üveg, létalapja a praktikum és az egészség. Megalkotja tehát a maga formamüvészetét üvegböl és vasból, áldozva igenis - szerénységgel és az élet szolgálatának alázatával, amint Ön mondja - a napfénynek, a higiéniának és a kényelem kultuszának, amelyek már önmagukban is egyenlök a szép kultuszával".

Gábor László választása, építészeti elkötelezettsége egyértelmúen az új építészet, a Bauhaus gyökerein táplálkozó modern építészet mellett áll.

Munkáinak bemutatását négy csoportba rendezve, villaépületeirôl, többlakásos bérházairól, a háború utáni építészeti tevékenységéről és egyetemi évei alatti munkásságáról kívánok szólni. Részletes jegyzék a tervezett épületekről, a teljes élet- 
műről nem áll rendelkezésemre, így a teljesség igénye nélkül csak példákra szorítkozom. A pályakezdő építész, de sokszor az érett alkotó is társakkal dolgozik, önálló építészként csak a világháború után dolgozott, így az ismertetett munkák jelentős része kollektív munkaként, alkotóközösségben készült, és többnyire az irodatulajdonos neve alatt került publikálásra.

\section{VILLAÉPÜLETEK}

Budapest, Berényi u. 6/b; Gellért hegy (Platschek Imre): A kétlakásos villa tervezésénél a telek adottságai jelentették a legtöbb gondot. A keresztirányban lejtő keskeny telek a gyalogos és a gépkocsi forgalom elválasztását indokolta. Az alagsori szint a garázst, kiszolgáló helyiségeket és a házmesterlakást, a felső két szint teraszokkal minden irányban megnyitott, két nagyméretű luxuslakást tartalmaz. Az épület vasbeton vázszerkezetű, kitöltő falakkal, kőszivacs és parafa hőszigeteléssel. A homlokzatfelületeket kővel burkolták. A lejtő irányú vízelvezetésre és vízvédelemre drainage-rendszer és négyrétegű szigetelés készült.

Az épület építészeti megjelenése összefogott, egyszerú, tiszta, nemes arányait az alagsori oszlopsor könnyeddé teszi. Háromirányú, mély loggiáira, melyeket a kedvező tájolás és kilátás is indokolt, nagyméretü, speciális kialakítású tolóablakok és erkélyajtók nyílnak. A szobákat többszárnyú tolóajtók kapcsolják össze. Az épület ma is lakóépületként múködik, a lakásokat leválasztották. Állaga elszomorító, felújításra szorul. Védettségére javaslatot kell tenni.

Budapest, Tigris u.46. (Platschek Imre): Háromszintes, nagyméretü családi villa a Naphegy déli lejtőjén. A teraszosított, lejtős domboldalra telepített épület első részben alagsori - szintjén a föbejárat, irodahelyiségek, házmesterlakás és a kiszolgáló helyiségek helyezkednek el, illetve innen indul a belső lépcső. A magasföldszinti alaprajz a nappali, étkezőkonyha és személyzeti helyiségeket foglalja magában, nagy, délkeleti tájolású loggiára nyílóan. A loggia az étkezőkonyha előtt szakaszosan kiszélesedik és egy íves rámpa közvetítésével kerti kapcsolata is megoldott. Az emeleten összenyitható négy hálószoba sor található, két fürdőszobával és öltözőszobákkal kiszolgálva, végigfutó loggiasorral kiegészítve.

Az épület monolit vasbeton vázszerkezettel készült. Az alaprajzi szervezés jellegzetessége, hogy a belső pillérváz kör oszlopai a válaszfalaktól függetlenül a térbe állítva jelennek meg. Az épület lapostetős kialakítású, homlokzatai kőburkolattal készülttek. Jelenleg az épület több lakásra tagolt, átalakított, rossz állapotú, védettségére javaslatot kell tenni.

Mindkét épületről megállapítható, hogy azonos elvek konzekvens végigvitelével készültek. Az egyszerü, összefogott tömegképzés, lapostetős kialakítás a kül- 
ső-belső terek kapcsolatrendszere, a jelentős homlokzati megnyitások, a flexibilis belső térszervezés mindkét épület sajátja. A nagyon igényes külső megjelenést az épületek elhelyezése, a kert és a külső környezet tudatos formálása egészíti ki. Mindkét épület ma is értékelhető építészeti minőséget képvisel.

\section{TÖBBLAKÁSOS ÉPÜLETEK}

Budapest, XI. Sztoczek u. 19. (Platschek Imre): Ötszintes, fogatolt lakóépület egy központi lépcsőház köré szervezett, különböző alapterületü lakásokkal. Az emeleti szinteken a lakásokat utcai-udvari loggiák egészítik ki. Az épület alápincézett, lapostetős kialakítású, utcai homlokzata kőburkolattal készült, udvari és oldalhomlokzatai vakoltak. A kőburkolat a háború alatt elpusztult. Az épület egyszerüsége ellenére lifttel kiszolgált, nagyvonalú előcsarnokból közelíthetők meg a lakások. Bejárati előtere, lépcsőháza igényes, szépen formált.

Bérház Debrecenben: A földszint + négyemeletes saroképület két lépcsőház köré szervezetten, szintenként 7 lakást tartalmaz. Az épület földszintjén üzletek nyertek elhelyezést. Az épület szokatlan puritánságát a nagyon szigorú gazdaságossági igény indokolta - tájékoztat a korabeli publikáció. Az épületnek ugyanazt a rentabilitást kellett biztosítania a befektetett tőke után, mint Budapesten, a Debrecenben elkérhető 40\%-kal alacsonyabb lakbérek mellett. Ez csak egyszerübb anyagok, szerkezetek felhasználásával volt lehetséges, de a földszint téglaburkolatára itt is lehetőséget talált a tervező.

Budapest, II. Margit körút 28. (Platschek Imre): Az 1934. évi építési adókedvezmény a Margit körút külső karéjának beépítését kedvezményezte, különösen akkor, ha az építés régi, hasznavehetetlen ház lebontásával valósul meg. Így létesült a Trust Nyugdíjegyesületi bérház a Margit körút ívében. A bérház két részből áll: a Margit körúti és a Mechwart-ligeti (téri) házakból. A bérleti és értékesítési szempontok a hátsó épület (a Mechwart ligeti szárny) megközelíthetőségét is a Margit körút felöl igényelték, ezért az épület földszintjén egy $12 \mathrm{~m}$ széles kapuzatot alakítottak ki, amely $4 \mathrm{~m}$ széles átjáróvá keskenyedik, és egy szépen parkosított udvaron keresztül biztosítja a hátsó szárny elérését. A Közmunka Tanács a két tömb összekötését és a szomszéd ház tűzfalának épülettel történő takarását írta elő. Mindkét épület lapostetős kialakítású, szépen formált tetőkertekkel.

Alaprajzi kialakitás: A tervezésnél alapelv volt, hogy a legkényelmesebb és legkorszerübb lakások készüljenek. A mellékhelyiségek legnagyobb részének közvetlen szellőzése van, a belső helyiségek gépi szellőzéssel frisslevegő utánpótlással ellátottak. A nagy épületmélységek miatt hall kialakítása vált szükségessé. 
Néhány szerkezeti megoldás: Az épület vázas szerkezetủ, részben vasbeton, részben acél vázszerkezettel, a kitöltő falak falazottak, kőszivacs hőszigeteléssel. A födémek téglabetétes vasbeton és vasbeton lemezfödémek. Az alapozást a kiterjedt épület két szárnya közötti jelentős szintkülönbség - mintegy két szint - bonyolította. Külön gondot jelentett a jelentkező rétegvíz-szigetelés megoldása és a víz elvezetése. Négyrétegủ szigetelés és drain-rendszer készült.

Az összes szerkezeti elem, anyag, megoldás a kor legjobb, legkorszerübb, esztétikailag legigényesebb megoldásával készült. A gépészeti rendszernél elég talán megemlíteni, hogy minden vezeték vörösrézből készült.

Budapest, II. Margit krt. 57.: A fszt + hatemeletes, háromfogatú, lapostetős épület a Margit körút külső oldalán, Kozma Lajos átriumháza mellett áll. Az egységes utcaképbe való illeszkedés volt a fő feladat. A földszinten széles kirakatszekrények, az emeleten nagyméretü erkélyek készültek. Alaprajzi szervezésére a racionalitás a jellemző. Az épület vázas szerkezetü, lapostetős kialakítással.

Budapest, XII. Szamos u. 5.: Publikációt, eredeti tervanyagot nem találtam. A saroképület megközelítése jellegzetes, az oszlopsorral megnyitott, fedett bejárati árkád, az íves erkélyek, sarokablakok tipikus motívumokat mutatnak.

Gábor László bérházépületeiről összefoglalva elmondható, hogy itt a kor elvárásainak megfelelően az építésznek a profitérdekelt befektető kívánságait ki kell szolgálnia, néha szakmai meggyőződése ellenére is. Az építészeti igényesség és a műszaki alaposság néha csak a lépcsőházon és a homlokzaton tud megjelenni, de mindig jelen van. A Margit körúti épület tekinthető a legigényesebbnek, itt a kor minden esztétikai és technikai vívmánya alkalmazásra került, talán ma sem lehetne jobban megtervezni.

\section{A II.VILÁGHÁBORÚT KÖVETŐ ALKOTÓ ÉVEK}

Belügyminisztérium: Gábor László 1946-48 között önálló építészként dolgozik, számos rekonstrukciós munkát készít, pályázaton vesz részt eredményesen. Legjelentősebb munkájának a budapesti Belügyminisztérium, ma Országgyülési Irodaház átépítési, rekonstrukciós munkája tekinthető, amelyet ifj. Benkhard Ágoston, Gádoros Lajos és Rudnai Gyula építészekkel közösen készített. Azért is érdemes néhány szót beszélni róla, mert az épület születésének körülményei a korra jellemző tanulságokat hordoznak.

Feladat volt egy korszerü hivatali épület létesítése, 600 szobával, előadóteremmel, 25-30 férőhelyes garázzsal, a szükséges kiszolgáló és szociális létesítmé- 
nyekkel, minisztériumi funkcióra, szerény eszközökkel, de az ország legnagyobb minisztériumát megillető reprezentatív megjelenéssel. Adottság volt egy elavult alaprajzú és szerkezetű, üzleti jelleggel létesített bérház, szűk belső udvarokkal, zavaros homlokzattal, ötletszerủen elhelyezett felépítményekkel. Az épületet a háború alatt több bombatalálat érte, részlegesen kiégett, födémjei leszakadtak. Szerkezeti rendszere középfőfalas, tégla-vasbeton-acél tartószerkezet ötletszerüen kombinálva, helyenként téglabetétes födémekkel. Egyedüli értéke az elhelyezkedés, a Duna-part, a körkilátás és a kialakuló kormányzati negyed közelsége. Ma egy ilyen épületet biztosan lebontanának. Az akkori kor szemlélete a takarékosság, az átépítés mellett döntött. Az oldalszárnyak kibontásával, a belső udvar beépítésével kialakított, tiszta, H-alaprajzú, központi forgalom-elosztású épület az elmúlt ötven évben használhatónak bizonyult.

\section{A MÜEGYETEM ÉPÜLETSZERKEZETI TANSZÉKÉN VÉGZETT ÉPÍTÉSZETI TEVÉKENYSÉG}

Külön elemzést igényelne, hogy egy alkotó energiái teljében lévő építészt mi késztet ilyen jelentős pályamódosításra, oktatói, tanszékszervezői-vezetői feladatok ellátására. Ismeretes az ideológiai váltás zűrzavara, az önállóság feladásának kényszere, az építés terén a tömegfeladatok előtérbe kerülése, az építési minőség színvonalcsökkenése. A kezdeti években (az 1950-es évek elején) még önálló építészi feladatokra is jut ideje, ekkor készült Lévai Andorral közös tervezésben a Maros utca 24-26-28. sz. alatti OTP társasház, ahol a korábbi kvalitásokból már csak a racionalitás maradt meg. Az 1960-as évek elején a Ganz utca 5-7. sz. alatti OTP társasház, illetve a debreceni irodaház tervezése során már csak menedzseri, tanácsadói feladatokat vállalt, ezt a készülő tankönyvek és egyetemi vezetői feladatai is magyarázzák. Tervezői aktivitása egy pillanatra újra fellángolt a Kovács Margit Gyüjtemény - majd a Múvésznő halála után - Kovács Margit Múzeum tervezése kapcsán, gondolatai, tanácsa, tévedhetetlen ízlése, érzékenysége nagymértékben hozzájárult a sikeres megvalósításhoz.

Zárszóként értékelnem kellene dr. Gábor László építészi tevékenységét. Nem teszem ezt két okból: egyrészt nem vagyok építészettörténész és elméleti szakember, másrészt rendkívül szoros - a munkatársi kapcsolaton túlmenően - baráti, szinte apa-fiú kapcsolatunk értékítéletem objektivitását esetleg elhomályosítja. Az én szememben és lelkemben Ő kiváló építész volt, odafigyelő, jó főnök, kellemes, szellemes, jó humorú EMBER, akire szívesen gondolok vissza, épületein, tankönyvein keresztül ható tanításait ma is nyugodt lelkiismerettel ajánlom az utókornak. 